\title{
DNA cleavage and antitumour activity of platinum(II) and copper(II) compounds derived from 4-methyl-2-N-(2- pyridylmethyl)aminophenol: spectroscopic, electrochemical and biological investigation
}

Article

Published Version

Roy, S., Maheswari, P.U., Lutz, M., Spek, A.L., den Dulk, H., Barends, S., van Wezel, G.P., Hartl, F. and Reedijk, J. (2009) DNA cleavage and antitumour activity of platinum(II) and copper(II) compounds derived from 4-methyl-2-N-(2pyridylmethyl)aminophenol: spectroscopic, electrochemical and biological investigation. Dalton Transactions (48). pp. 10846-10860. ISSN 1364-5447 doi:

https://doi.org/10.1039/b911542k Available at https://centaur.reading.ac.uk/11592/

It is advisable to refer to the publisher's version if you intend to cite from the work. See Guidance on citing.

To link to this article DOI: http://dx.doi.org/10.1039/b911542k

Publisher: Royal Society of Chemistry 
All outputs in CentAUR are protected by Intellectual Property Rights law, including copyright law. Copyright and IPR is retained by the creators or other copyright holders. Terms and conditions for use of this material are defined in the End User Agreement.

\section{www.reading.ac.uk/centaur}

\section{CentAUR}

Central Archive at the University of Reading

Reading's research outputs online 
This paper is published as part of a Dalton Transactions themed issue on:

\title{
Metal Anticancer Compounds
}

\author{
Guest Editor Peter Sadler \\ University of Warwick, UK
}

Published in issue 48, 2009 of Dalton Transactions

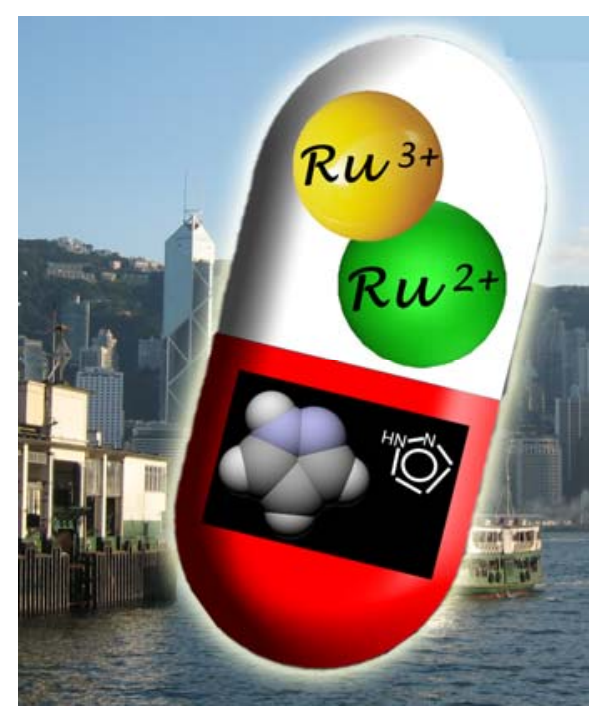

Image reproduced with permission of Chi-Ming Che

Articles published in this issue include:

\section{PERSPECTIVES:}

Non-traditional platinum compounds for improved accumulation, oral bioavailability, and tumor targeting

Katherine S. Lovejoy and Stephen J. Lippard, Dalton Trans., 2009, DOI: 10.1039/b913896j

Metal complexes as photochemical nitric oxide precursors: Potential applications in the treatment of tumors

Alexis D. Ostrowski and Peter C. Ford, Dalton Trans., 2009, DOI: 10.1039/b912898k

Novel and emerging approaches for the delivery of metallo-drugs

Carlos Sanchez-Cano and Michael J. Hannon, Dalton Trans., 2009, DOI: 10.1039/b912708a

\section{HOT ARTICLE:}

$\underline{\text { Iron(III) complexes of fluorescent hydroxamate ligands: preparation, properties, and cellular }}$ processing

Antonia J. Clarke, Natsuho Yamamoto, Paul Jensen and Trevor W. Hambley, Dalton Trans., 2009, DOI: 10.1039/b914368h

Visit the Dalton Transactions website for more cutting-edge inorganic and bioinorganic research www.rsc.org/dalton 


\title{
DNA cleavage and antitumour activity of platinum(II) and copper(II) compounds derived from 4-methyl-2- $N$-(2-pyridylmethyl)aminophenol: spectroscopic, electrochemical and biological investigation $\uparrow$ t
}

\author{
Sudeshna Roy, ${ }^{a}$ Palanisamy Uma Maheswari, ${ }^{a}$ Martin Lutz, ${ }^{b}$ Anthony L. Spek, ${ }^{b}$ Hans den Dulk, ${ }^{a}$ \\ Sharief Barends, ${ }^{a}$ Gilles P. van Wezel, ${ }^{a}$ František Hartl ${ }^{c, d}$ and Jan Reedijk ${ }^{* a}$
}

Received 12th June 2009, Accepted 4th September 2009

First published as an Advance Article on the web 13th October 2009

DOI: $10.1039 / \mathrm{b} 911542 \mathrm{k}$

The reaction of the redox-active ligand, Hpyramol (4-methyl-2- $N$-(2-pyridylmethyl)aminophenol) with $\mathrm{K}_{2} \mathrm{PtCl}_{4}$ yields monofunctional square-planar [Pt(pyrimol)Cl], $\mathrm{PtL}-\mathrm{Cl}$, which was structurally characterised by single-crystal X-ray diffraction and NMR spectroscopy. This compound unexpectedly cleaves supercoiled double-stranded DNA stoichiometrically and oxidatively, in a non-specific manner without any external reductant added, under physiological conditions. Spectro-electrochemical investigations of $\mathrm{PtL}-\mathrm{Cl}$ were carried out in comparison with the analogue $\mathrm{CuL}-\mathrm{Cl}$ as a reference compound. The results support a phenolate oxidation, generating a phenoxyl radical responsible for the ligand-based DNA cleavage property of the title compounds. Time-dependent in vitro cytotoxicity assays were performed with both $\mathrm{PtL}-\mathrm{Cl}$ and $\mathrm{CuL}-\mathrm{Cl}$ in various cancer cell lines. The compound $\mathrm{CuL}-\mathrm{Cl}$ overcomes cisplatin-resistance in ovarian carcinoma and mouse leukaemia cell lines, with additional activity in some other cells. The platinum analogue, PtL-Cl also inhibits cell-proliferation selectively. Additionally, cellular-uptake studies performed for both compounds in ovarian carcinoma cell lines showed that significant amounts of $\mathrm{Pt}$ and $\mathrm{Cu}$ were accumulated in the A2780 and A2780R cancer cells. The conformational and structural changes induced by $\mathrm{PtL}-\mathrm{Cl}$ and $\mathrm{CuL}-\mathrm{Cl}$ on calf thymus DNA and $\phi$ X174 supercoiled phage DNA at ambient conditions were followed by electrophoretic mobility assay and circular dichroism spectroscopy. The compounds induce extensive DNA degradation and unwinding, along with formation of a monoadduct at the DNA minor groove. Thus, hybrid effects of metal-centre variation, multiple DNA-binding modes and ligand-based redox activity towards cancer cell-growth inhibition have been demonstrated. Finally, reactions of PtL-Cl with DNA model bases (9-Ethylguanine and 5'-GMP) followed by NMR and MS showed slow binding at Guanine-N7 and for the double stranded self complimentary oligonucleotide $\mathrm{d}(\mathrm{GTCGAC})_{2}$ in the minor groove.

\section{Introduction}

The serendipitous discovery of cisplatin and its extensive usage as an antitumour drug have initiated investigations in the medicinal bioinorganic research field towards numerous platinum compounds. Multifactorial resistance (intrinsic or acquired) and severe toxicity limit the prolonged administration of cisplatin, having fuelled search for more potent metallodrugs with less

${ }^{a}$ Leiden Institute of Chemistry, Gorlaeus Laboratories, Leiden University, P.O. Box 9502, 2300 RA, Leiden, The Netherlands

${ }^{b}$ Bijvoet Center for Biomolecular Research, Crystal and Structural Chemistry, Utrecht University, Padualaan 8, 3584 CH, Utrecht, The Netherlands 'Van't Hoff Institute for Molecular Sciences, University of Amsterdam, Nieuwe Achtergracht 166, $1018 \mathrm{WV}$, Amsterdam, The Netherlands

'Department of Chemistry, University of Reading, Whiteknights, Reading, UK RG6 6AD

$\dagger$ Electronic supplementary information (ESI) available: Tables 1 and S2 provide the crystallographic details and bond distances and angles for the compound PtL-Cl. Figs. S1-S12 show the data on crystal packing of PtL$\mathrm{Cl}$, and details of the characterisation with cellular uptake, DNA binding, ESI-MS and NMR spectroscopic data. CCDC reference number 735958. For ESI and crystallographic data in CIF or other electronic format see DOI: $10.1039 / \mathrm{b} 911542 \mathrm{k}$

$\$$ Paper dedicated to the memory of the late Lloyd Kelland. systemic toxicity and internal resistance. ${ }^{1-3}$ The other platinum anticancer drugs in clinical practise, or in current clinical trials, include platinum(II)-containing oxaliplatin, carboplatin, picoplatin (JM473), nedaplatin (JM118), or redox-active platinum(IV)based satraplatin, tetraplatin and ormaplatin. Some of these second or third generation compounds are stable through cell metabolism, ${ }^{1,3,4}$ overcome the limitations by less systemic toxicity, have better bio-availability and even display improved antitumour activity.

Genomic DNA is most likely the main cellular target for platinum drugs. Especially for cisplatin it has been demonstrated that the major antitumour activity originates from intrastrand crosslinks and the formation of DNA kinks. ${ }^{5}$ Therefore DNA targeting drugs remain in the limelight and compounds acting towards cancer cells selectively over healthy cells, are getting more attention. ${ }^{6-10}$ The detailed investigation of cisplatin activation, biotransformation, accumulation, coordinative binding, DNA kinking and unwinding explains much of the antitumour activity of this drug, originating from DNA damage. ${ }^{11}$ In recent literature, there are some reports on 'rule-breaker' platinum compounds which are highly active against tumour cells. ${ }^{12-14}$ These approaches are focused on the design of compounds that may form adducts 
a)

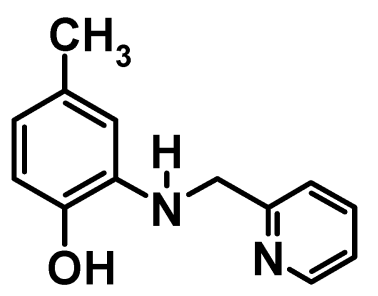

Hpyramol

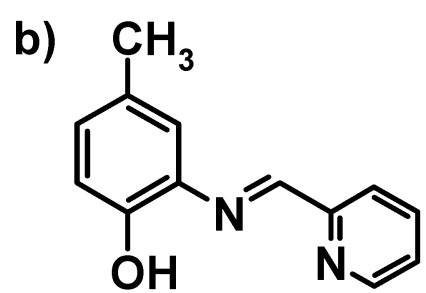

Hpyrimol

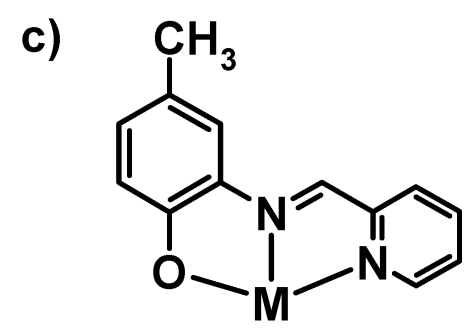

M-pyrimol

Fig. 1 Schematic structures of (a) Hpyramol, (b) its dehydrogenated form and (c) coordinated to a metal ion.

with DNA, differently than the classical cisplatin. The mode of interaction of newly designed platinum compounds with target biomolecules can be directed either via coordinative (interstrand crosslinking), or via non-coordinative (intercalation, electrostatic, groove-binding or hydrogen-bonding) interactions. ${ }^{15,16}$

The mono-substituted adduct of cisplatin with guanine has proved to be more genotoxic than the bis-guanine adducts. ${ }^{17}$ Based on this evidence recently some interesting platinum complexes have been synthesised and investigated which are classified as 'monofunctional' metallodrugs. ${ }^{18,19}$ These complexes possess a single labile chloride and therefore after hydrolysis under physiological conditions, they can form only mono-adducts with DNA bases. ${ }^{20-22}$ Some of them exhibit interesting antiproliferative activity with increased DNA binding affinity. The monofunctional Pt-ACRAMTU series reported by Bierbach et al. ${ }^{18}$ for example preferably target the DNA minor groove selectively, due to the presence of a directing intercalator moiety.

Another approach to new antineoplastic metallodrugs could be by making use of the well-known 'chemical nucleases'. This class of compounds cleave DNA in several pathways namely (a) nucleobase oxidation, (b) phosphate ester hydrolysis and (c) deoxyribose sugar oxidation. Such molecular scissors can cleave DNA either by single or double strand breaks. The cellular response from the living organelles against this damage is the activation of multi-faceted repairing mechanisms such as base excision repair, double strand break repair, crosslink repair and nucleotide excision repair. The most efficient chemical nucleases contain transition metal ions, like the redox-active $\mathrm{Cu}, \mathrm{Fe}$, or the redox-inactive $\mathrm{Zn}$ in their active sites. The classic examples of this type of artificial nucleases used as antitumour drugs are bleomycin and some of its metal-coordinated derivatives along with $\left[\mathrm{Cu}(\text { phen })_{2}\right]^{+}$-based complexes. ${ }^{23}$

From our earlier work, a unique ligand 4-methyl-2- $N$-(2pyridylmethyl)aminophenol (Hpyramol) ${ }^{24}$ forming a compound with $\mathrm{CuCl}_{2}$ (square planar $[\mathrm{Cu}$ (pyrimol)Cl], $\mathrm{CuL}-\mathrm{Cl}$ ) was reported to cleave DNA oxidatively and catalytically without any added reductant and to exhibit high to moderate antitumour activity against selected cancer cell lines. The ligand alone is also redox active in solution, but devoid of any DNA cleaving or antineoplastic property towards most cancer cell lines on its own. The protonated ligand form, Hpyrimol (HL), appears to be formed by direct Hpyramol oxidation. Upon metal-ion coordination Hpyramol undergoes oxidative dehydrogenation and concomitant deprotonation to give the anionic ligand 4-methyl2- $N$-(2-pyridylmethylene)aminophenolate (pyrimol, $\mathrm{L}^{-}$). A schematic diagram of the ligand, its several forms and coordination patterns with metals is presented in Fig. 1. When coordinated to redox-inactive $\mathrm{Zn}$ (II), the Hpyramol ligand cleaves $\phi \mathrm{X} 174$ supercoiled phage DNA through a non-diffusible ligand-based radical mechanism. ${ }^{25,26}$

These highly surprising results inspired us to react Hpyramol with platinum(II), which is known to be redox-inactive under physiological conditions; possibly a new potent DNA-targeting anticancer drug might result, that could eventually induce cell death by cleaving the cellular DNA efficiently and irreversibly. Hence, the analogue PtL-Cl was synthesised and structurally characterised by X-ray crystal structure determination, NMR and other experimental techniques as reported below, to correlate the DNA cleavage property and its in vitro cytotoxicity towards cancer cell lines. The compounds, $\mathrm{PtL}-\mathrm{Cl}$ and reference $\mathrm{CuL}-\mathrm{Cl}$, were tested for the growth-inhibition of cultured tumour cells. The total drug uptake in the selective cancer cells was also measured. The compound PtL-Cl cleaved $\phi$ X174 phage DNA, as shown by agarose gel electrophoresis, at more than stoichiometric ratio. High resolution PAGE (PolyAcrylamide Gel Electrophoresis) gel experiments were performed to observe any sequence-specific DNA cleavage by PtL-Cl. As DNA is the most expected target here, PtL-Cl was allowed to interact with calf thymus DNA and $\phi$ X174 supercoiled phage DNA. Circular dichroism was used to monitor any conformational changes on its binding. The reactions of $\mathrm{PtL}-\mathrm{Cl}$ with the model bases 9-ethylguanine and 5 -GMP were followed by ${ }^{1} \mathrm{H}$ and ${ }^{195} \mathrm{Pt}$ NMR to investigate the stability of the mono-adduct with the guanine residue on DNA. The compound PtL-Cl was reacted with self-complementary d(GTCGAC $)_{2}$ oligonucleotide to detect any solution structural changes upon interaction. A detailed spectro-electrochemical analysis and comparison of the redox behaviour of PtL-Cl with $\mathrm{CuL}-\mathrm{Cl}$ and Hpyrimol were performed to obtain support for the ligand-based radical-induced oxidative DNA damage caused by PtL-Cl.

\section{Experimental section}

\section{Materials}

9-Ethylguanine (9-EtG) and Guanosine-5'-monophosphate (5'-GMP) were purchased from Sigma-Aldrich B.V. The $\phi \mathrm{X} 174$ supercoiled phage DNA used for DNA cleavage studies was purchased from Invitrogen Life Technology $(0.25 \mu \mathrm{g} / \mu \mathrm{L})$. Deuterated solvents used for NMR experiments were also purchased from 
Sigma-Aldrich. $\mathrm{K}_{2} \mathrm{PtCl}_{4}$ was used from a generous loan scheme by Johnson-Matthey (Reading, U.K.). The ligand Hpyramol (4-methyl-2- $N$-(2-pyridylmethyl)aminophenol) was synthesised in a single-step reaction as reported in the literature. ${ }^{24}$ The solvents used in the syntheses were purchased from Biosolve (AR grade) and used without further purification.

\section{Syntheses}

[Pt(pyrimol)Cl], (PtL-Cl). An aerobic ethanolic solution of the precursor ligand, Hpyramol (51.6 $\mathrm{mg}, 0.24 \mathrm{mmol})$ was added in the dark drop-wise to an aqueous solution of $\mathrm{K}_{2} \mathrm{PtCl}_{4}(100 \mathrm{mg}$, $0.24 \mathrm{mmol}$ ) and stirred at $50^{\circ} \mathrm{C}$ for $24 \mathrm{~h}$. The reaction mixture was filtered while warm and the filtrate was evaporated to $5 \mathrm{~mL}$ under reduced pressure. A deep green precipitate was obtained by cooling down this concentrated filtrate at $4{ }^{\circ} \mathrm{C}$ overnight. The precipitate was washed with cold ethanol $(3 \times 2 \mathrm{~mL})$, then with diethyl ether $(3 \times 5 \mathrm{~mL})$ and dried under suction in the dark. Yield: $65.98 \mathrm{mg}$ (62\%). Elemental analysis for $\mathrm{C}_{13} \mathrm{H}_{11} \mathrm{~N}_{2}$ OClPt: C, 35.34; H, 2.50; N, 6.34 (Calcd.), C, 35.25; H, 2.42; N, 6.10 (Expt.). The green precipitate was characterised as $\mathrm{Pt}$ (pyrimol)Cl by ${ }^{1} \mathrm{H},{ }^{13} \mathrm{C},{ }^{195} \mathrm{Pt}$, 2-D COSY and ${ }^{1} \mathrm{H}^{-13} \mathrm{C}$ HETCOR spectroscopy. ${ }^{195} \mathrm{Pt}$ NMR shows a single peak at $-2326 \mathrm{ppm}$ (in DMSO- $d_{6}$ ) and $-2322 \mathrm{ppm}$ (in $\mathrm{DMF}$ ), corresponding to a $\mathrm{PtN}_{2} \mathrm{OCl}$ coordination environment. Single crystals suitable for X-ray diffraction were grown in the dark from a concentrated DMSO solution in the NMR tube.

[Cu(pyrimol)Cl], (CuL-Cl). The compound $\mathrm{CuL}-\mathrm{Cl}$ was reproduced by following the method already reported. ${ }^{26} \mathrm{~A}$ deepred crystalline powder was characterised by elemental analysis, infrared and EPR spectroscopy. A good match with the literature data was observed.

\section{X-ray crystal structure determination of PtL-Cl}

Single crystals suitable for X-ray diffraction were obtained directly from an NMR tube which contained a concentrated DMSO- $d_{6}$ solution of PtL-Cl and was kept at ambient temperature in the dark. X-ray intensities were measured on a Nonius KappaCCD diffractometer with a rotating anode (graphite monochromator, $\lambda=0.71073 \AA$ ) at $-123{ }^{\circ} \mathrm{C}$. Data were integrated with EvalCCD ${ }^{27}$ using an accurate description of the experimental setup for the prediction of the reflection contours. Absorption correction and scaling were performed with the program SADABS. ${ }^{28}$ The structure was solved by application of automated Patterson methods (DIRDIF-99 ${ }^{29}$ ). The refinement was performed with SHELXL$97^{30}$ against $\mathrm{F}^{2}$ of all reflections. Non-hydrogen atoms were refined with anisotropic displacement parameters. All hydrogen atoms were located in difference-Fourier maps and refined with a riding model. Geometry calculations and checking for higher symmetry were performed with the PLATON program. ${ }^{31}$ Further details of the molecular structure of PtL-Cl are given in Table 1 and in Supplementary Information (Table S1).†

\section{NMR experiments}

The one-dimensional $\left({ }^{1} \mathrm{H}\right.$ and $\left.{ }^{13} \mathrm{C}\right)$ and two-dimensional COSY and HETCOR spectra were recorded on a $600 \mathrm{MHz}$ Bruker DPX600 spectrometer at ambient temperature $\left(24^{\circ} \mathrm{C}\right)$ in DMSO$d_{6}$. The ${ }^{195} \mathrm{Pt}$ spectra were recorded on a $300 \mathrm{MHz}$ Bruker
Table 1 Crystal data and structure refinement for the compound PtL-Cl
$\mathrm{C}_{13} \mathrm{H}_{11} \mathrm{ClN}_{2} \mathrm{OPt}$

441.76

dark red

$0.21 \times 0.03 \times 0.03$

$150(2)$

0.71073

triclinic

$\mathrm{P} \overline{1}$ (no. 2)

$7.1447(3)$

$8.5058(3)$

$10.2432(3)$

$83.230(2)$

$76.509(1)$

$87.059(2)$

600.91(4)

2

2.442

11.884

multi-scan

$0.36-0.70$

0.65

$9030 / 2743$

$164 / 0$

$0.0246 / 0.0492$

$0.0355 / 0.0518$

0.0403

1.050

$-1.05 / 0.94$

spectrometer with a $5 \mathrm{~mm}$ multi-nucleus probe at $24^{\circ} \mathrm{C}$ in DMSO$d_{6}$ and non-deuterated DMF solvents. For ${ }^{195} \mathrm{Pt} \mathrm{NMR}, \mathrm{Na}_{2} \mathrm{PtCl}_{6}$ was used as external reference set at $\delta=0 \mathrm{ppm}$.

\section{Biological studies}

(a) Cells and culture conditions. The $100 \mathrm{~mm}$ culture and micro-well plates were received from NUCLON (Roskilde, Denmark). MTT [3-(4,5-dimethylthiazol-2-yl)2,5-diphenyltetrazoliumbromide] was purchased from Sigma-Aldrich B.V. The human ovarian carcinoma cell lines, cisplatin sensitive (A2780) and cisplatin resistant (A2780R), were generous gifts from Dr. J. M. Perez (Universidad Autonoma de Madrid, Spain). The mouse leukemia cell lines, cisplatin sensitive (L1210/0) and cisplatin resistant (L1210/2), were used for the MTT assay as well. The cells were grown as monolayers in Dulbecco's Modified Eagle's Medium (DMEM) supplemented with 10\% fetal calf serum (Gibco, Paisley, Scotland), penicillin (100 units/mL; Dufecha, The Netherlands) and streptomycin $(100 \mu \mathrm{g} / \mathrm{mL}$; Dufecha, The Netherlands). During the culture period the cells grew partly in suspension and partly adhered to the flask wall.

\section{(b) Cytotoxicity assays.}

MTT assay. The cell survival was evaluated by a typical MTT colorimetric method ${ }^{32}$ albeit slightly modified. Cells were plated onto 96-well sterile plates (Corning Co.) in $100 \mu \mathrm{L}$ of medium at a density of $2 \times 10^{3}$ cells per well and incubated for $48 \mathrm{~h}$ at $37{ }^{\circ} \mathrm{C}$ in a $7 \% \mathrm{CO}_{2}$ containing incubator. The compound was added at six different concentrations. The final concentrations ranged from $0.4 \mu \mathrm{M}$ to $90 \mu \mathrm{M}$. As the stock solution of PtL-Cl was made in DMF, in order to see the solvent effect, DMF was used as the blank. For comparison the starting ligand (Hpyramol) and cisplatin were tested in the same plate and the stocks in both cases were made in DMF. In addition, for comparison with the reported 
value of $\mathrm{IC}_{50}$ for cisplatin (in water) the latter was also tested as in a typical aqueous solutions. A freshly prepared MTT solution $(5 \mathrm{mg} / \mathrm{mL})$ in PBS buffer was added to each well $(50 \mu \mathrm{L}$ per well $)$ after $48 \mathrm{~h}$ of incubation. The plates were then again incubated at $37^{\circ} \mathrm{C}$ for $3 \mathrm{~h}$. All the supernatant liquid was removed very carefully without disturbing the blue crystals stuck at the bottom of the plates. The MTT was metabolised by the mitochondrial reduction of the living cancer cells and transformed to a blue formazan product. These crystals were dissolved in $100 \mu \mathrm{L}$ DMSO per well and were shaken carefully until the crystals were completely dissolved to give a purple solution. The absorbance of each well was determined at $590 \mathrm{~nm}$ by using a Model 550 Bio-Rad microplate reader. All the tests were performed in quadruplicate for each cell line. The $\mathrm{IC}_{50}$ values were calculated from the curves drawn by plotting \% cell survival versus compound concentration (in $\mu \mathrm{M}$ ) using the program Graphpad Prism, version 3.0, 2000. ${ }^{16}$ The $\mathrm{IC}_{50}$ value indicates the amount of drug needed for $50 \%$ growth inhibition of the cancer cells relative to untreated (drug-free cancer cells).

$S R B$ assay. The cytotoxicities of $\mathrm{PtL}-\mathrm{Cl}, \mathrm{CuL}-\mathrm{Cl}$ and the ligand Hpyramol were analysed using the microculture sulforhodamine B (SRB) test, ${ }^{33}$ carried out commercially with TEVA-Pharmachemie (Haarlem, The Netherlands). Human tumour cell lines analysed were WIDR, IGROV, M19-MEL, A498 and H226, which belong to the currently used anti-cancer screening panel of the National Cancer Institute, $\mathrm{USA}^{34}$ with additional two breast cancer cell lines, i.e., MCF-7 (containing estrogen and progesterone receptors) and EVSA-T (lacking both hormone receptors). All cell lines were maintained in a continuous logarithmic culture in the RPMI 1640 medium with the Hepes buffer and phenol red. The medium was supplemented with $10 \% \mathrm{FCS}$, penicillin $(100 \mathrm{IU} / \mathrm{mL})$ and streptomycin $(100 \mu \mathrm{g} / \mathrm{mL})$. The cells were mildly trypsinised for passage and for the use in the experiments. Trypsinised tumour cells $\left(150 \mu \mathrm{L}\right.$, containing $2 \times 10^{3}$ cells/well $)$ were pre-incubated for $48 \mathrm{~h}$ at $37{ }^{\circ} \mathrm{C}$ in 96 -well flat-bottom cell culture plates. The tested compounds were added in a three-fold dilution series up to and including $62.5 \mu \mathrm{g} / \mathrm{mL}$. After 7 days the cells were fixed with $10 \% \mathrm{TCA}$ in the PBS buffer and incubated at $4{ }^{\circ} \mathrm{C}$ for $1 \mathrm{~h}$. After three times washing with water the cells were stained for 15 min with $0.4 \% \mathrm{SRB}$ in $1 \%$ acetic acid. Subsequently the cells were washed with $1 \%$ acetic acid, air-dried and the bound stain dissolved in $150 \mu \mathrm{L} 10 \mathrm{mM}$ Tris-base (unbuffered). The value of $\mathrm{A}_{540}$ was assessed using an automated microplate reader (Labsystems Multiskan MS). Data were used for concentrationresponse curves and $\mathrm{ID}_{50}$ values using Deltasoft 3 software (Biometallics Inc., Princeton, NJ, USA). ${ }^{16}$ Subsequent conversion of units provided the $\mathrm{IC}_{50}$ values for all samples tested.

(c) Cellular uptake experiments. Cells of the A2780 and A2780R cell lines were plated in sterile 6-well plates in $5 \mathrm{~mL}$ of Dulbecco's Modified Eagle's Medium (DMEM) at a density of $1 \times 10^{5}$ cells per well and incubated for $48 \mathrm{~h}$. The cisplatin, $\mathrm{CuL}-\mathrm{Cl}$ and $\mathrm{PtL}-\mathrm{Cl}$ were added to the plates at the ultimate concentration of $200 \mathrm{nM}$, and incubated for 2, 6 and $24 \mathrm{~h}$. Afterwards the cells were washed twice with $5 \mathrm{~mL}$ PBS per well and triton (lysis buffer) was added $(350 \mu \mathrm{L}$ per well) to lyse the cells. After transferring the pellet to Eppendorf tubes, 10\% SDS $(100 \mu \mathrm{L}$ per well $)$ and Proteinase $\mathrm{K}(20 \mu \mathrm{g} / \mathrm{mL}$ and $1 \mathrm{~mL}$ per well) were added. Then the viscous pellets were incubated at $55^{\circ} \mathrm{C}$ for $30 \mathrm{~min}$ and $1.5 \mathrm{~mL} \mathrm{20} \% \mathrm{HNO}_{3}$ was added. After shaking for $45 \mathrm{~min}$ the samples were measured by Varian Vista-MPX chargecoupled simultaneous ICP-OES (Inductively Coupled Plasma Optical Emission Spectroscopy) to estimate of $\% \mathrm{Pt}$ and $\% \mathrm{Cu}$ taken up by the cancer cells. To compare the accumulation of Pt-moieties inside the cisplatin sensitive, A2780 cells, timedependent uptake studies were also performed for PtL-Cl at $2 \mathrm{~h}$ intervals for up to $24 \mathrm{~h}$. The active concentration of $\mathrm{PtL}-\mathrm{Cl}$ used for the time-dependent measurement was $50 \mu \mathrm{M}$.

(d) DNA cleavage studies. $\phi \mathrm{X} 174$ supercoiled phage DNA was purchased from Invitrogen Life Technologies and stored at $-20^{\circ} \mathrm{C}$. A typical reaction mixture, containing supercoiled plasmid DNA and PtL-Cl in a $10 \mathrm{mM}$ phosphate buffer at $\mathrm{pH} 7.2$, was incubated at $37^{\circ} \mathrm{C}$ for $2 \mathrm{~h}$ (with or without additives, or without any external reductant). After the incubation period, the reaction was quenched by keeping the samples at $-20{ }^{\circ} \mathrm{C}$, followed by the addition of loading buffer (bromophenol blue, xylene cyanol, and $25 \%$ ficoll). This was then loaded on a $0.8 \%$ agarose gel containing ethidium bromide ( $2.54 \mu \mathrm{M}$ in the gel as well as in the buffer). The gels were run at a constant voltage of $80 \mathrm{~V}$ for $60-90 \mathrm{~min}$ in the TBE buffer containing ethidium bromide. After washing with distilled water, the gels were visualised under a UV transilluminator and the bands were documented and quantified using a BioRad Gel Doc 1000 apparatus interfaced with a computer.

(e) High resolution denaturing gel electrophoresis.

Preparation of oligonucleotides and PAGE. For the high resolution analysis of the DNA cleavage process, a doublestranded oligonucleotide was used. The synthetic procedure to prepare this type of oligonucleotides has a coupling efficiency of $97-99 \%$. Therefore, in each step, a short side product is formed, whose intensity on the electrophoresis gel is associated with the coupling efficiency (a 99\% efficiency implies that $1 \%$ side product is present, $97 \%$ gives $3 \%$ side product and so on). Consequently, the electrophoresis reveals a ladderlike pattern, with a weak band at each nt (nucleotide) position. This is ideally suited for the detailed analysis of the cleavage mechanism. A $54 \mathrm{nt}$ oligonucleotide FNA1 (DNA sequence 5'-GATCCTGGTGGAGCTAAGCGGGATCGAACCGCT-GACCTCTTGCTTGCATAGCAA-3') was radiolabelled with $\left[\gamma_{-}{ }^{32} \mathrm{P}\right]$ ATP (MP Biomedicals) using T4 polynucleotide kinase (Fermentas) as indicated by the supplier, and purified over S200 spin columns (GE healthcare), effectively removing all products up to $15 \mathrm{nt}^{35}$ Duplex DNA was obtained by annealing the $10 \mu \mathrm{M} \quad\left[{ }^{32} \mathrm{P}\right]$-labelled FNA1 with an equimolar amount of oligonucleotide FNA2 (5'AGCGCTTGCTATGCAAGCAAGAGGTCAGCGGTTCGATCCCGCTTAGCTCCACCA-3') in $250 \mathrm{mM} \mathrm{NaCl}$ solution at $70{ }^{\circ} \mathrm{C}$ for $2 \mathrm{~min}$, followed by slow cooling to ambient temperature. On either side, the probe has 5 nucleotides of a single-stranded region at the $5^{\prime}$ end (underlined in the oligonucleotides). For copper-induced cleavage experiments, the FNA1/2 duplex DNA was incubated at a concentration of $100 \mu \mathrm{M}$ bp with $20 \mu \mathrm{M}$ of compound, $\mathrm{CuL}-\mathrm{Cl}$ at $37{ }^{\circ} \mathrm{C}$. At indicated time intervals (0-60 min), samples were taken and quenched with an equal volume of stop solution $\left(90 \%\right.$ [v/v] formamide and $50 \mathrm{mM} \mathrm{H}_{4}$ edta) at $-20{ }^{\circ} \mathrm{C} .{ }^{26}$ DNA was incubated at a concentration of $100 \mu \mathrm{M} \mathrm{bp}$ with $50 \mu \mathrm{M}$ and $200 \mu \mathrm{M}$ of platinum compound, PtL-Cl at $37{ }^{\circ} \mathrm{C}$ at indicated time intervals (0-150 $\mathrm{min})$. Samples were separated 
by high resolution denaturing PAGE $(15 \%)$ and visualised by phosphor imaging (Bio-Rad).

Enzymatic religation. pUC19 plasmid DNA was treated with PtL-Cl, CuL-Cl, or with the restriction enzyme BamH1, without any reductant, at $37^{\circ} \mathrm{C}$ and at $\mathrm{pH}$ 7.2. DNA samples were purified over QIAquick PCR purification columns (Qiagen) and used for religation experiments. The ligation reaction was performed in a $20 \mu \mathrm{L}$ volume using $50 \mathrm{ng}$ of the digested DNA products with 2 units of T4 DNA ligase (Fermentas) for $16 \mathrm{~h}$ at $16{ }^{\circ} \mathrm{C}$.

(f) Circular dichroism. Circular dichroism spectra were recorded at $37^{\circ} \mathrm{C}$ using a Jasco J-815 spectropolarimeter equipped with a Jasco PTC-423 S Peltier temperature controller. The scanning rate was $100 \mathrm{~nm} / \mathrm{min}$ with a response time $1 \mathrm{~s}$. Spectra were recorded at standard sensitivity $(100 \mathrm{mdeg})$ with a data-pitch of $0.5 \mathrm{~nm}$ in continuous mode. The scanning range was $320-220 \mathrm{~nm}$ and all the spectra were average of four consequent accumulations. The cuvettes used were $2 \mathrm{~mm}$ Quartz Suprasil precision cells (Hellma). The baseline was corrected using $10 \mathrm{mM}$ phosphate buffer as a reference. Volume of sample in the cuvettes was kept constant at $700 \mu \mathrm{L}$.

A typical sample containing DNA (Calf thymus DNA or supercoiled $\phi$ X174 phage DNA) and metal compounds (PtL-Cl or $\mathrm{CuL}-\mathrm{Cl}$ ) in phosphate buffer was incubated at $37^{\circ} \mathrm{C}$ and the $\mathrm{CD}$ spectra were collected at the given time intervals. As references, cisplatin and the free ligand, Hpyramol were also interacted with DNA under similar conditions as followed for PtL-Cl or CuL-Cl.

(g) Electrochemical studies. Cyclic voltammetry of $1 \times 10^{-3} \mathrm{M}$ $\mathrm{PtL}-\mathrm{Cl}$ in a single-compartment cell was carried out with an Autolab PGstat10 potentiostat (Eco Chemie) controlled by GPES4 software, or with an EG\&G PAR Model 283 potentiostat operated with the PAR Power $\mathrm{CV}^{\circledR}$ software. The DMF solutions contained $10^{-1} \mathrm{M} \mathrm{Bu}_{4} \mathrm{NPF}_{6}$ as the supporting electrolyte. The three-electrode system consisted of a carefully polished $\mathrm{Pt}$ disk working electrode, a Pt auxiliary electrode, and an $\mathrm{Ag} / \mathrm{AgCl}$ reference electrode. The voltammetric response of the standard ferrocene/ferrocenium $\left(\mathrm{Fc} / \mathrm{Fc}^{+}\right)$couple was found in this system at $+0.43 \mathrm{~V} v s \mathrm{Ag} / \mathrm{AgCl}$. The air-tight UV-Vis spectroelectrochemical cell employed for the in situ oxidation of $2 \times 10^{-3} \mathrm{M}$ of PtL-Cl and the ligands Hpyramol and Hpyrimol at room temperature, has been described in detail elsewhere. ${ }^{36}$ The electrode potential was controlled during the in situ electrolyses by a PA4 potentiostat (EKOM, Polná, Czech Republic). UV-Vis spectra were recorded with a HP 8453 diode array spectrophotometer.

\section{(h) Reactions with model bases.}

NMR experiments. The compound PtL-Cl $(4 \mathrm{mM})$ was allowed to react with 9-ethylguanine and 5'-GMP at different stoichiometric ratios. The solvents used were DMSO- $d_{6}$ (for 9-Ethyl guanine) and DMSO- $d_{6} / \mathrm{D}_{2} \mathrm{O}$ mixture (for $5^{\prime}$-GMP) studies in an NMR tube. The reactants were mixed prior to the measurements, where the time interval between the mixing and recording of the first spectrum was maximum 15 min The experimental temperature was maintained at $37^{\circ} \mathrm{C}$ (for pseudo-physiological conditions) for overnight series ${ }^{1} \mathrm{H}$ NMR experiments. After $14 \mathrm{~h}$ the samples were kept in a water bath for maximum 30 days at $37^{\circ} \mathrm{C}$ and spectra were recorded at different time-intervals. ${ }^{195} \mathrm{Pt}$ NMR spectra were recorded after 24 and $48 \mathrm{~h}$ to observe the changes in the $\mathrm{Pt}$ coordination sphere.
ESI-MS measurements. All the spectra were recorded on a Finnigan AQA instrument equipped with electrospray interface (ESI). The reactions between PtL-Cl and model bases (9-ethylguanine and 5'-GMP) were followed by ESI-MS at time intervals of max $15 \mathrm{~min}$ up to $3 \mathrm{~h}$, and also after $24 \mathrm{~h}$. The solvents used were DMSO and a DMSO $/ \mathrm{H}_{2} \mathrm{O}$ 1:1 mixture (v/v) for the two model bases, respectively. The samples from the NMR tubes were also directly used to identify reaction products.

(i) NMR Solution studies with d(GTCGAC) ${ }_{2}$. ${ }^{1} \mathrm{H}$ NMR spectra were recorded on a Bruker $600 \mathrm{MHz}$ spectrometer. The temperature was varied from 7 to $47^{\circ} \mathrm{C}$ to determine the fast exchange kinetics. Afterwards the 2-D NOESY spectra were recorded by the method ${ }^{37}$ of States et al. using 2048 data points in $t_{2}$ for $256 t_{1}$ values with a pulse repetition delay of $2 \mathrm{~s}$ at $17^{\circ} \mathrm{C}$ or $27^{\circ} \mathrm{C}$. DQF-COSY experiments were also accumulated using 2048 data points in $t_{2}$ for $256 t_{1}$ values with a pulse repetition delay of $2 \mathrm{~s}$. Spectra recorded in $90 \% \mathrm{H}_{2} \mathrm{O}$ and $10 \% \mathrm{D}_{2} \mathrm{O}$ were collected using the WATER GATE solvent suppression technique of Piotto et al. ${ }^{38}{ }^{1} \mathrm{H}$ chemical shifts are relative to (tetramethylsilyl)propionic acid (TSP) as internal standard. Typical samples contained $1 \mathrm{mM}$ d(GTCGAC) $)_{2}$ duplex, 1 or $2 \mathrm{mM} \mathrm{PtL}-\mathrm{Cl}, 20 \mathrm{mM} \mathrm{NaCl}$ in $\mathrm{D}_{2} \mathrm{O}$, and $10 \mathrm{mM}$ phosphate buffer $(\mathrm{pH}=7)$ in $0.5 \mathrm{~mL}$ of $\mathrm{H}_{2} \mathrm{O}$.

\section{Results and discussion}

\section{Synthesis}

The chemical synthesis of PtL-Cl is straightforward and successfully completed in a single step. $\mathrm{K}_{2} \mathrm{PtCl}_{4}$ and the ligand Hpyramol are reacted in equimolar ratio to yield the compound PtL-Cl as a crystalline green powder. The spectroscopic and elemental analyses prove the formation as PtL-Cl. The ${ }^{195} \mathrm{Pt}$ NMR shows a single peak (at-2326 ppm), which is in the region common for $\mathrm{PtN}_{3} \mathrm{O}$ and $\mathrm{PtN}_{3} \mathrm{Cl}$ coordination environments. ${ }^{39,40}$ No evidence is observed of any fold-back signal, so the single peak can be attributed to a $\mathrm{PtN}_{2} \mathrm{OCl}$ environment. No attempts were undertaken to study the stepwise dehydrogenation of Hpyramol in the presence of $\mathrm{K}_{2} \mathrm{PtCl}_{4}$ under anaerobic conditions or otherwise, as the reactions had always been performed under aerobic conditions. The ESI-MS of PtL-Cl in DMSO solution shows a major peak at $m / z=484.32$, which corresponds to the cation [Pt(pyrimol)(dmso) $]^{+}$formed after the solvolysis of relatively labile chloride ligand by DMSO. The $\mathrm{C}, \mathrm{H}, \mathrm{N}$ elemental analysis also fits with the elemental percentage calculated for PtL-Cl.

\section{Crystal structure description}

Needle shaped single crystals of PtL-Cl were obtained by slow evaporation of a concentrated DMSO- $d_{6}$ solution in an NMR tube at ambient temperature under exclusion of day light. The crystal structure shows the starting ligand Hpyramol to dehydrogenate and coordinate to $\mathrm{Pt}(\mathrm{II})$ through the $\mathrm{N}_{2} \mathrm{O}$-binding motif, which results in an almost square-planar geometry with cis angles between $81.74(15)^{\circ}$ and $99.14(11)^{\circ}$ (Fig. 2). The molecular structure is quite similar to the reported $\mathrm{CuL}-\mathrm{Cl}{ }^{26}$ but the packing in the crystal lattice is completely different, apparently due to the co-crystallised $\mathrm{H}_{2} \mathrm{O}$ in $\mathrm{CuL}-\mathrm{Cl}$. The planar PtL-Cl molecules are stacked on top of each other in an anti-parallel fashion in the direction of the crystallographic $a$-axis (Fig. S1 $\dagger$ ) with 


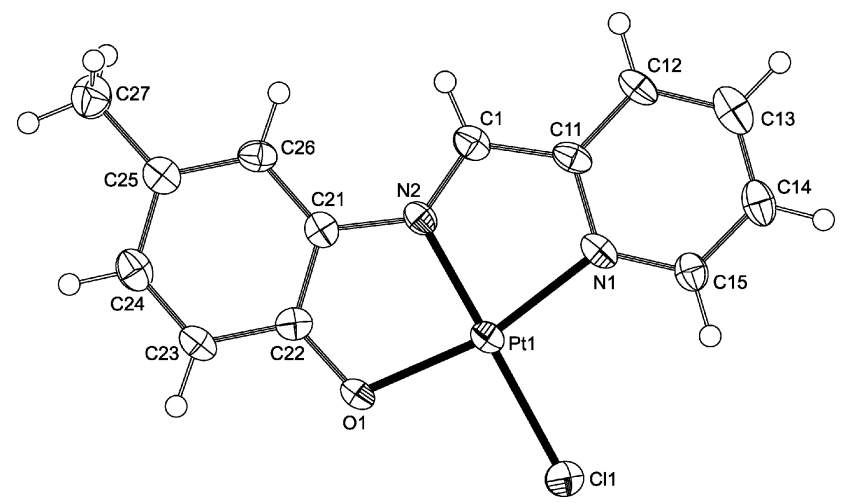

Fig. 2 Displacement ellipsoid plot of PtL-Cl in the crystal $(50 \%$ probability level).

intermolecular Pt...Pt distances of 5.0418(3) and 4.7540(3) $\AA$. The corresponding interplanar distances are 3.43 and $3.31 \AA$, respectively. Besides this molecular stacking no other strong intermolecular interactions could be detected. This observation is understandable, as no strong hydrogen bond donors are present. Consequently the long dimension of the needle shaped crystals corresponds to the crystallographic $a$-axis. In $\mathrm{CuL}-\mathrm{Cl}$ there is also anti-parallel molecular stacking in the $a$-direction, with $\mathrm{Cu} \cdots \mathrm{Cu}$ distances of 5.1647(3) and 6.1325(3) $\AA$ and interplanar distances of both $3.34 \AA$; however, the stacks are linked with each other by intermolecular hydrogen bonds involving the co-crystallised $\mathrm{H}_{2} \mathrm{O}$ molecules. More relevant crystallographic data for PtL-Cl are available in the Supporting Information (Tables 1 and $\mathrm{S} 1 \dagger$ ).

\section{Cytotoxicity assays}

MTT assay. The in vitro cytotoxicity tests were performed for human ovarian carcinoma and mouse leukemia cancer cell lines (See Experimental for details). The $\mathrm{IC}_{50}$ values (in $\mu \mathrm{M}$ ) are summarised in Table 2 with their respective standard deviations. In ovarian carcinoma cell line (both cisplatin sensitive and resistant) the $\mathrm{IC}_{50}$ values for PtL-Cl are very high $(22.4$ and $43.6 \mu \mathrm{M}$, respectively), which indicates its low activity when compared to leukemia cell line (8.1 and $27.5 \mu \mathrm{M}$, respectively). The $\mathrm{IC}_{50}$ values in cisplatin resistant cell lines are higher than in cisplatin sensitive cell lines, which is generally observed. In leukemia cell lines PtL-Cl overcomes cisplatin resistance to some extent as evident from the $\mathrm{RF}$ value of 3.4. Therefore, the compound $\mathrm{PtL}-\mathrm{Cl}$ is active towards leukemia cell line and moderately active towards ovarian carcinoma cell lines. $\mathrm{CuL}-\mathrm{Cl}$ shows very high antiproliferative properties in these four cell lines, as in all cases the $\mathrm{IC}_{50}$ values are similar or even lower than the $\mathrm{IC}_{50}$ values for cisplatin itself and this compound overcomes cross-resistance to cisplatin in both types of cancer cell lines. On the other hand, free Hpyramol is active in ovarian carcinoma cell lines, but in leukemia cell lines it exhibits almost no activity. It is therefore evident that the cytotoxicity profile has changed significantly after coordination with $\mathrm{Pt}(\mathrm{II})$ or $\mathrm{Cu}(\mathrm{II})$. For comparison cisplatin was also tested after dissolution in DMF, similarly as PtL-Cl and free ligand. It is evident from the table that the $\mathrm{IC}_{50}$ values calculated for cisplatin (in DMF) are quite different than the $\mathrm{IC}_{50}$ values for cisplatin in aqueous solution. This observation indicated that, although DMF is known as a weakly coordinating solvent, in some cases it can also act like a coordination solvent (replacing coordinated chloride) and the solvated species can result in a different biodistribution.

The effect of different times of incubation on the activity towards cell lines has also been investigated. The cytotoxic activity of $\mathrm{PtL}-\mathrm{Cl}$ was found to be reduced with longer incubation time. The $\mathrm{IC}_{50}$ values are increased by 2-fold (A2780), 3-fold (A2780R), 18-fold [L1210(0)] and 4-fold [L1210(2)], respectively. When the incubation time is shorter, $\mathrm{CuL}-\mathrm{Cl}$ exhibits a high activity, i.e. as high as cisplatin, whereas longer incubation times repress the activity. The results are shown in Table 2 for incubation times $48 \mathrm{~h}$ and $120 \mathrm{~h}$. The loss of activity in resistant cell lines, A2780R and $\mathrm{L} 1210(2)$ is more significant than in the case of the cisplatin sensitive, A2780 and L1210(0) cell lines. The prolonged incubation time reduced the activity of $\mathrm{CuL}-\mathrm{Cl}$ up to eighteen to twenty times in cell lines tested. The differences can be explained by either by increased efflux, or by increased cellular assimilation of the biologically relevant metal ion, $\mathrm{Cu}(\mathrm{II})$, in $\mathrm{CuL}-\mathrm{Cl}$. In case of cisplatin and PtL-Cl, the results can be explained also by enhanced efflux and slower cellular uptake.

SRB assay. Seven human tumour cell lines with different origin were used to test the activity of PtL-Cl and $\mathrm{CuL}-\mathrm{Cl}$. For cisplatin and $\mathrm{CuL}-\mathrm{Cl}$ stock solutions were made in MilliQ water, while for PtL-Cl, DMSO is used to make the stock solution. The results are summarised in Table 3 . The activity profile clearly shows a dependence on the time of incubation. For all cell lines, the activity of cisplatin was found higher with prolonged incubation.

The activity of cisplatin after $120 \mathrm{~h}$ of incubation was six to twelve times higher than after $48 \mathrm{~h}$ of incubation. This difference

Table $2 \mathrm{IC}_{50}$ values in $\mu \mathrm{M}$ of samples against human ovarian carcinoma and mouse leukaemia cancer cell lines (cisplatin sensitive and resistant) after $48 \mathrm{~h}$ and $120 \mathrm{~h}$ of incubation

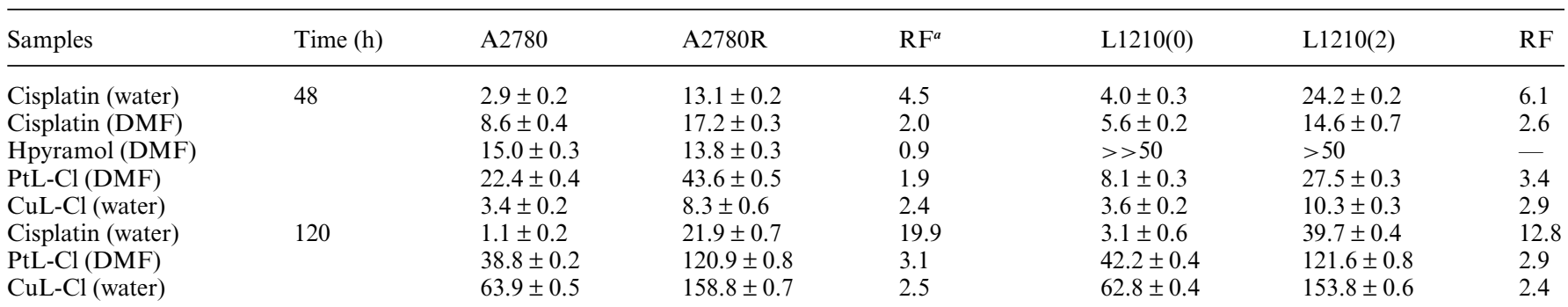

${ }^{a}$ The Resistance Factor (RF) is defined as the relative ratio of $\mathrm{IC}_{50}$ values in resistant and sensitive variety of similar cell lines, e.g., A2780R/A2780 or $\mathrm{L} 1210(2) / \mathrm{L} 1210(0)$, respectively. $\mathrm{IC}_{50}$ value is defined as the amount of a compound needed to inhibit $50 \%$ of cell growth. The deviations are incorporated with the values. 
Table $3 \mathrm{IC}_{50}$ values in $\mu \mathrm{M}$ of samples against seven human tumour cell lines after $48 \mathrm{~h}$ and $120 \mathrm{~h}$ of incubation

\begin{tabular}{|c|c|c|c|c|c|c|c|c|}
\hline Samples & Time (h) & A498 & EVSA-T & H226 & IGROV & M19-MEL & MCF-7 & WIDR \\
\hline Cisplatin & 48 & 8.2 & 17.2 & 10.4 & 3.0 & 9.7 & 16.3 & 21.1 \\
\hline PtL-Cl & & 51.5 & 26.2 & 69.5 & 24.8 & 59.3 & 31.5 & 50.9 \\
\hline CuL-Cl & & 33.4 & 1.3 & 29.4 & 18.6 & 2.2 & 21.4 & 36.2 \\
\hline Cisplatin & 120 & 6.2 & 2.5 & 2.1 & 0.74 & 2.3 & 2.7 & 1.8 \\
\hline PtL-Cl & & 8.8 & 38.4 & 56.6 & 45.2 & 54.4 & 27.4 & 62.7 \\
\hline CuL-Cl & & 4.3 & 10.6 & 11.5 & 17.2 & 1.5 & 10.6 & 29.9 \\
\hline
\end{tabular}

can be explained by higher accumulation over a longer time-period and reduced efflux. In the case of $\mathrm{PtL}-\mathrm{Cl}$, there is no smooth trend of change. The activity of PtL-Cl, in the A498 cell line, was increased by six folds after $120 \mathrm{~h}\left(\mathrm{IC}_{50}\right.$ values range $51.5 \mu \mathrm{M}$ to $8.8 \mu \mathrm{M})$ incubation. In the $\mathrm{H} 226$ and $\mathrm{MCF}-7$ cell lines the activity of PtL-Cl was found to be enhanced as well. For other cell lines no prominent effect of time-period of incubation was noticed. The significant change in activity was also observed in the case of $\mathrm{CuL}-\mathrm{Cl}$. In the A498, H226 and MCF-7 cell lines the activity of $\mathrm{CuL}-\mathrm{Cl}$ was found increased by seven, two and two times, respectively. In the other three cell lines, i.e. IGROV, M19-MEL and WIDR, the activity of $\mathrm{CuL}-\mathrm{Cl}$ was also found increased, but to a smaller extent. A completely contrasting behaviour was observed in the EVSA-T cell line, where the activity of $\mathrm{CuL}-\mathrm{Cl}$ is repressed by almost eight times upon longer incubation times. Apparently the changes in activity profile are strongly dependent on the time of incubation and consequently on uptake and efflux, deactivation and interaction with cellular targets.

The variability of the in vitro cytotoxicity test depends on the cell line used and the serum applied. With the same batch of cell lines and the same batch of serum the interexperimental CV (coefficient of variation) is $1-11 \%$ depending on the cell line, and the intraexperimental $\mathrm{CV}$ is $2-4 \%$. These values may be higher when using other batches of cell lines and/or serum.

\section{Uptake of PtL-Cl and CuL-Cl in ovarian carcinoma cells}

In order to explain the huge difference in the cytotoxicities (PtL-Cl and $\mathrm{CuL}-\mathrm{Cl}$ ), uptake studies have been performed in
A2780 and A2780R cell lines. The amount of $\mathrm{Pt}$ or $\mathrm{Cu}$ which were taken up by both cisplatin sensitive and resistant ovarian carcinoma is shown in Figs. $3 a$ and $3 b$, respectively. In the A2780 cell line the platinum compounds, both cisplatin and PtL-Cl, were accumulated increasingly inside the cells with gradual increase in incubation time, whereas the $\mathrm{Cu}$-compound, $\mathrm{CuL}-\mathrm{Cl}$, is accumulated at its highest concentration after $24 \mathrm{~h}$ incubation. The amount of $\mathrm{Pt}$ accumulated inside the A2780 cells is similar when compared to cisplatin, which is not at the same line with its lower cytotoxicity. The $\mathrm{Cu}$-accumulation does not follow any smooth trend as after $6 \mathrm{~h}$ there is some excretion and after $24 \mathrm{~h}$ a significant amount of $\mathrm{Cu}$ can be detected. This extent of accumulation can easily explain the high activity of compound $\mathrm{CuL}-\mathrm{Cl}$ in ovarian carcinoma cell lines.

In resistant cell lines the same trend was followed by the platinum compounds, but maximum accumulation of $\mathrm{Cu}$ was found to be achieved after $24 \mathrm{~h}$, after some initial excretion at $6 \mathrm{~h}$. As the resistant cell lines are obtained after multiple exposures of cell lines to cisplatin over a certain time period, the uptake of Pt-compounds is expected to be lower than for the sensitive counterpart. The data observed for cisplatin are in agreement with the expected value, even though PtL-Cl exhibits a different behaviour. Although a significant amount of platinum derived from the compound PtL-Cl was detected and shown to be accumulated in a higher amount compared to cisplatin in the cell, the low cytotoxicity cannot be directly related. The deactivation by cellular platinophiles can be the most plausible explanation. On the contrary, $\mathrm{Cu}$ is more abundant in the physiological environment; the cellular uptake for $\mathrm{Cu}$-compound would be
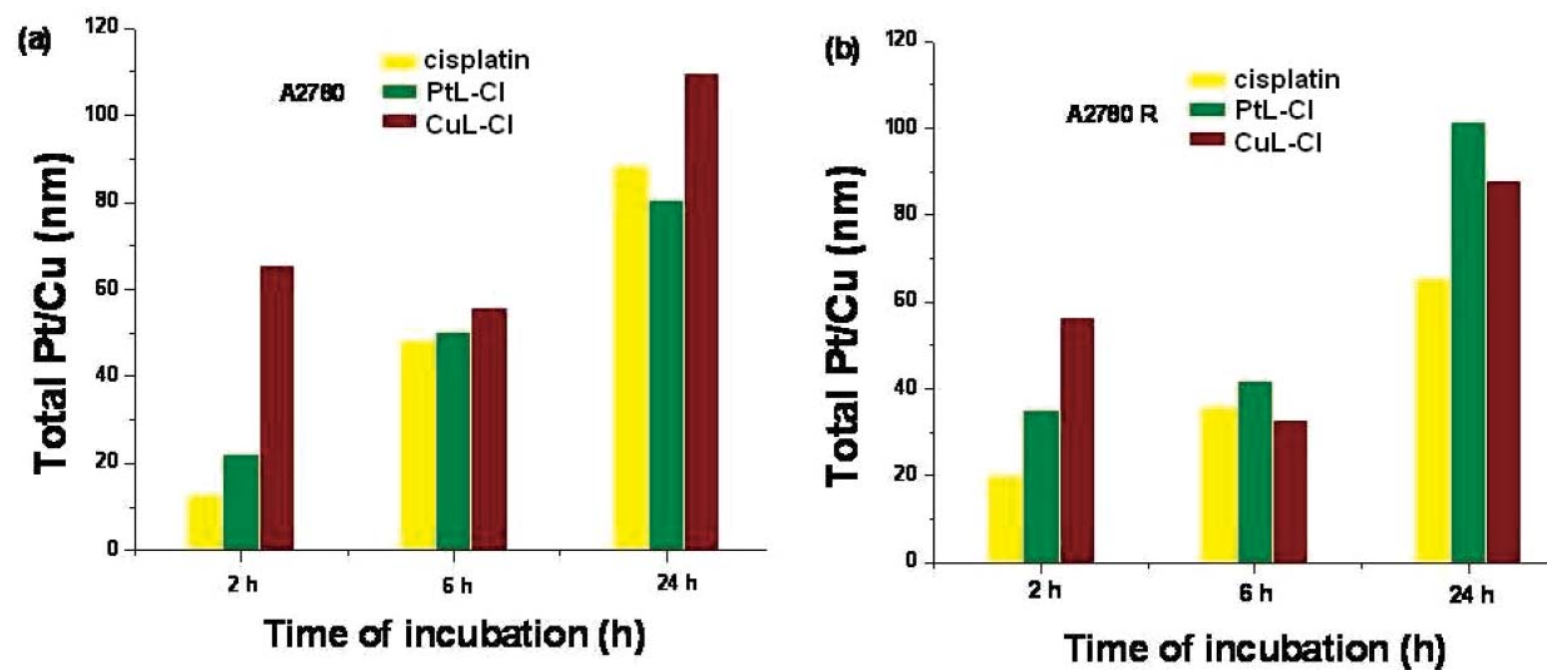

Fig. 3 Amount of Pt/Cu accumulated inside (a) A2780 and (b) A2780R cell-lines at different incubation times from cisplatin, PtL-Cl and CuL-Cl. 


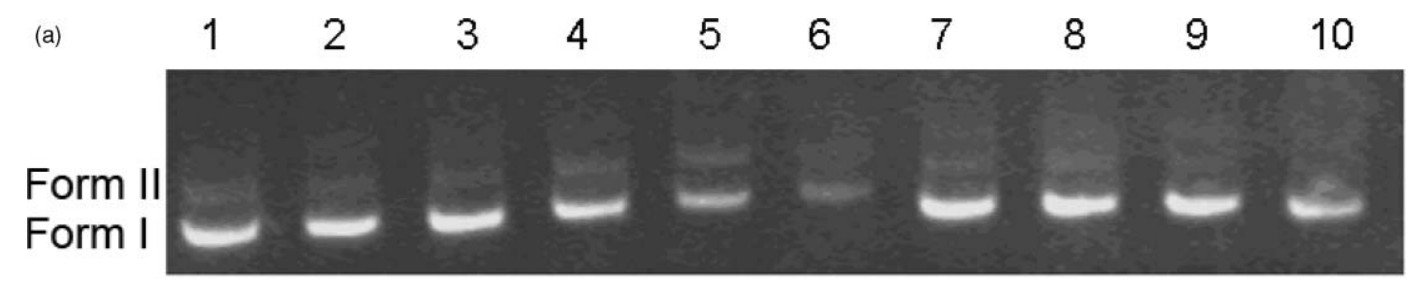

(b)

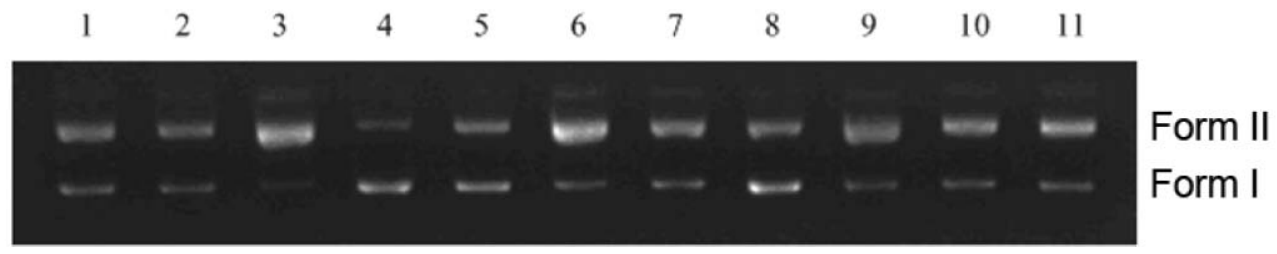

Fig. 4 a. Agarose gel electrophoresis of $\phi \mathrm{X} 174$ supercoiled phage DNA incubated with PtL-Cl at $37^{\circ} \mathrm{C}$, in the phosphate buffer at pH $=7.2$. Lane 1, DNA blank $(20 \mu \mathrm{M}$ in base pairs), lane $2,20 \mu \mathrm{M}$ DNA $+10 \mu \mathrm{M}$ of PtL-Cl, lane 3, $20 \mu \mathrm{M}$ DNA $+20 \mu \mathrm{M}$ of PtL-Cl, lane 4, $20 \mu \mathrm{M}$ DNA + $50 \mu \mathrm{M}$ of PtL-Cl, lane 5, $20 \mu \mathrm{M}$ DNA $+100 \mu \mathrm{M}$ of PtL-Cl, lane 6, $20 \mu \mathrm{M}$ DNA $+200 \mu \mathrm{M}$ of PtL-Cl, lane 7, $20 \mu \mathrm{M}$ DNA $+10 \mu \mathrm{M}$ of PtL-Cl + $20 \mu \mathrm{M}$ ascorbic acid, lane 8, $20 \mu \mathrm{M}$ DNA $+20 \mu \mathrm{M}$ ascorbic acid, lane 9, $20 \mu \mathrm{M}$ DNA $+10 \mu \mathrm{M}$ of PtL-Cl $+20 \mu \mathrm{M}$ TEMPO, lane 10, $20 \mu \mathrm{M}$ DNA + $20 \mu \mathrm{M}$ TEMPO. b. Agarose gel electrophoresis of the oxidative cleavage reaction of $\phi \mathrm{X} 174$ supercoiled phage DNA ( $20 \mu \mathrm{M}$ in base pairs) with PtL-Cl (100 $\mu \mathrm{M})$ without reductant after an incubation time of $2 \mathrm{~h}$ at $37^{\circ} \mathrm{C}$ in the phosphate buffer at $\mathrm{pH}=7.2$ (lanes $\mathbf{1 0}$ and 11), in the presence of the following species: for lane 1, $200 \mu \mathrm{M} \mathrm{NaN}_{3}$; lane 2, DMSO; lane 3, $0.5 \mathrm{U}$ of superoxide dismutase; lane 4, $100 \mu \mathrm{M}$ distamycin; lane 5, ethanol; lane 6, $\mathrm{D}_{2} \mathrm{O}$; lane 7, 350 mM NaCl; lane 8, reaction performed under an argon atmosphere; lane 9, reaction with exclusion of light.

expected to be faster than for the toxic metal compounds, cisplatin and PtL-Cl. The uptake or accumulation pathway of the $\mathrm{CuL}-\mathrm{Cl}$ is most likely to be different from that of platinum compounds, as relatively higher amounts of $\mathrm{Cu}$ can be detected.

In order to quantify the amount of platinum accumulated inside the A2780 cells with a certain time interval $(2 \mathrm{~h})$, a separate experiment was performed with $50 \mu \mathrm{M}$ of $\mathrm{PtL}-\mathrm{Cl}$. The maximum accumulation observed after $18 \mathrm{~h}$ of incubation but the time-scale of cancer cell-cycle is around $24 \mathrm{~h}$. The changes in the amount of platinum accumulated inside the cells do not follow a specific trend, which may be interesting to be studied in more details. In Fig. S2 $\uparrow$ the concentration of platinum inside the cell versus incubation time has been plotted to draw a correlation of the uptake-accumulation and cytotoxicity in vitro for compound PtL-Cl. After the initial higher accumulation of $\mathrm{Pt}$ in cells, the efflux process becomes most probably activated and the amount of total platinum inside the cells gradually decreases. After $10 \mathrm{~h}$ of incubation, the uptake and accumulation is starting to reach the highest concentration at $18 \mathrm{~h}$. After that time PtL-Cl appears to be excreted from the cells and the accumulation of platinum after $24 \mathrm{~h}$ is relatively higher than the initial accumulation. This study, however, do not follow the same trend as described above (with $200 \mathrm{nmol} / \mathrm{L}$ active concentration of PtL-Cl). Therefore, after a complete cell-cycle a significant accumulation of platinum has taken place, although it cannot be correlated with the in vitro cytotoxicity data. This behaviour can be explained by platinum removal or deactivation with platinophiles inside the cells.

\section{DNA cleavage studies}

Agarose gel electrophoresis. The DNA cleaving ability of PtL-Cl was investigated on reaction with $\phi$ X174 supercoiled phage DNA and relative mobility of the products on agarose gel. PtL-Cl (20-200 $\mu \mathrm{M})$ was incubated with DNA $(20 \mu \mathrm{M}$ in base pairs) for $2 \mathrm{~h}$ at $37^{\circ} \mathrm{C}$ in phosphate buffer $(\mathrm{pH}=7.2)$, with or without additives and reductant. On binding of an increasing amount of PtL-Cl, the DNA shows significant retardation in mobility during electrophoresis (Fig. 4a; illustrated by the slower migration of the bands), most likely caused by the increased amount of adduct formation between the DNA and the metal compound. The smear above the DNA is most likely indicative of the disintegration of the complex between PtL-Cland DNA during electrophoresis. Interestingly, little difference is observed in terms of DNA cleavage between $0-20 \mu \mathrm{mol} / \mathrm{L} \mathrm{PtL-Cl}$, suggesting that DNA cleavage only occurs after binding of multiple molecules of metal compounds. This is supported by the observation that at concentrations of $50 \mu \mathrm{M}$ and higher extensive cleavage is seen, with complete obliteration of the DNA at $200 \mu \mathrm{M}$, and that hardly any nicked DNA (Form II, resulting from a single cleavage event) and no linear DNA (Form III, double-strand cleavage) is observed. During oxidative cleavage a more canonical cleavage pattern was observed, with discrete bands and the expected formation of Form II (Fig. 4b). This observation illustrates that under these conditions nicking occurs on the intact (full-length) $\phi X 174$ DNA, while the absence of linear DNA highlights the lack of double-strand cleavage. The added reductant (lane 7, $100 \mu \mathrm{M}$ ascorbic acid) or the radical scavenger (lane 9, $20 \mu \mathrm{M}$ TEMPO) do not affect the cleavage activity of PtL-Cl. With $200 \mu \mathrm{M}$ $\mathrm{PtL}-\mathrm{Cl}$, the DNA is completely digested. Thus, PtL-Cl behaves differently from $\mathrm{CuL}-\mathrm{Cl}$, as the latter compound cleaves DNA oxidatively and catalytically. ${ }^{26}$ With this concentration-dependent experiment, however, "single-strand nicking" and "non-catalytic (stoichiometric) cleavage" processes are difficult to discriminate with certainty.

The DNA cleavage reactions carried out with $\mathrm{PtL}-\mathrm{Cl}$ are not inhibited by the presence of various radical scavengers, that is, $\mathrm{NaN}_{3}$, superoxide dismutase, DMSO, ethanol or $\mathrm{D}_{2} \mathrm{O}$ (Fig. 4b). The use of distamycin highly inhibits the DNA cleavage and an excess of $\mathrm{NaCl}$ does not inhibit the cleavage of DNA, and Form II is still detected if the digestion is performed under argon, 
or reaction with exclusion of light. These results point to the binding of PtL-Cl preferably in the minor groove as competed by distamycin, and to non-diffusible radical pathways of DNA cleavage.

High-resolution analysis of the cleavage process. To study the non-oxidative cleavage phenomenon in more detail, high resolution DNA electrophoresis studies were performed, which allowed for the separation of DNA fragments with single nucleotide resolution (see below). This experiment was performed using a $5^{\prime}$ radiolabelled double-stranded oligonucleotide, which was known to produce a ladder of bands inherent to the fact that each coupling step occurs with a $98-99 \%$ efficiency. The samples were then run on a $15 \%$ denaturing gel, to allow identification of DNA fragments at single nucleotide resolution. Excitingly, while the control lane clearly showed individual bands, on progressive degradation these simply became fainter (more prominent for $200 \mu \mathrm{M}$ DNA and 90 min incubation), eventually producing a continuous 'smear' (Fig. 5). This smearing is most likely the result of the cleavage process and is not due to excessive background, as highlighted by the intensity of the smear below the lowest nucleotide band (15 nucleotide (nt), see bottom part of Fig. 5). PtL-Cl, therefore attacks the DNA at multiple sites without any specificity like the $\mathrm{CuL}-\mathrm{Cl}$. In fact $\mathrm{CuL}-\mathrm{Cl}$ degrades the DNA in a very non-specific manner, perhaps attacking the base and/or the sugar in multiple positions (Fig. 5).

The mode of DNA cleavage activity (oxidative or hydrolytic) towards pUC19 DNA by compound PtL-Cl and $\mathrm{CuL}-\mathrm{Cl}$ was investigated by transformation to $E$. coli competent cells. DNA was linearised with a restriction enzyme (BamHI) (as a control), or incubated with one of the compounds PtL-Cl or CuL-Cl.
Next, DNA was purified to remove the excess of metal compounds, dissolved in water, and measured by the nano-drop spectrophotometer to determine its concentration exactly. The digestion mixture ( $5 \mathrm{ng}$ ) was then religated by T4 DNA ligase and transformed to fresh competent cells of E. coli, to determine the number of colony forming units ( $\mathrm{CFU})$. Comparison of the transformation efficiencies of uncleaved pUC19 DNA with the control experiment (BamHI digested and religated using DNA T4 ligase) showed that the ligation efficiency was close to $95 \%$. Each experiment was performed in triplicate, giving highly reproducible results.

In Fig. 6 DNA digested with the restriction enzyme BamHI is set to $100 \%$ religation efficiency, since restriction enzymes generate intact $3^{\prime}$ - and $5^{\prime}$ - DNA ends that form a perfect template for ligation. For the copper compound, the bar is somewhat lower, indicating that the religation efficiency is reduced by just over an order of magnitude, while the very low bar for the Pt complex indicates approximately 1000-fold lower religation efficiency compared to the restriction enzyme. The formation of DNA ends that cannot be religated strongly suggests oxidative cleavage, as this process will result in template ends that are not recognized by the DNA ligase. The high religation efficiency observed with DNA digested by $\mathrm{CuL}-\mathrm{Cl}$, shows that the oxidative DNA cleavage efficiency of the CuL-Cl compound is lower than that of PtL-Cl for the same amount of pUC19 DNA; however it is still significant. The fact that $\mathrm{Pt}(\mathrm{II})$ is unlikely to change valence state in this process, points towards a phenoxyl-based process.

\section{Circular dichroism}

The DNA conformational changes induced by PtL-Cl, CuL-Cl and Hpyramol were investigated by $\mathrm{CD}$ spectroscopy. Typical

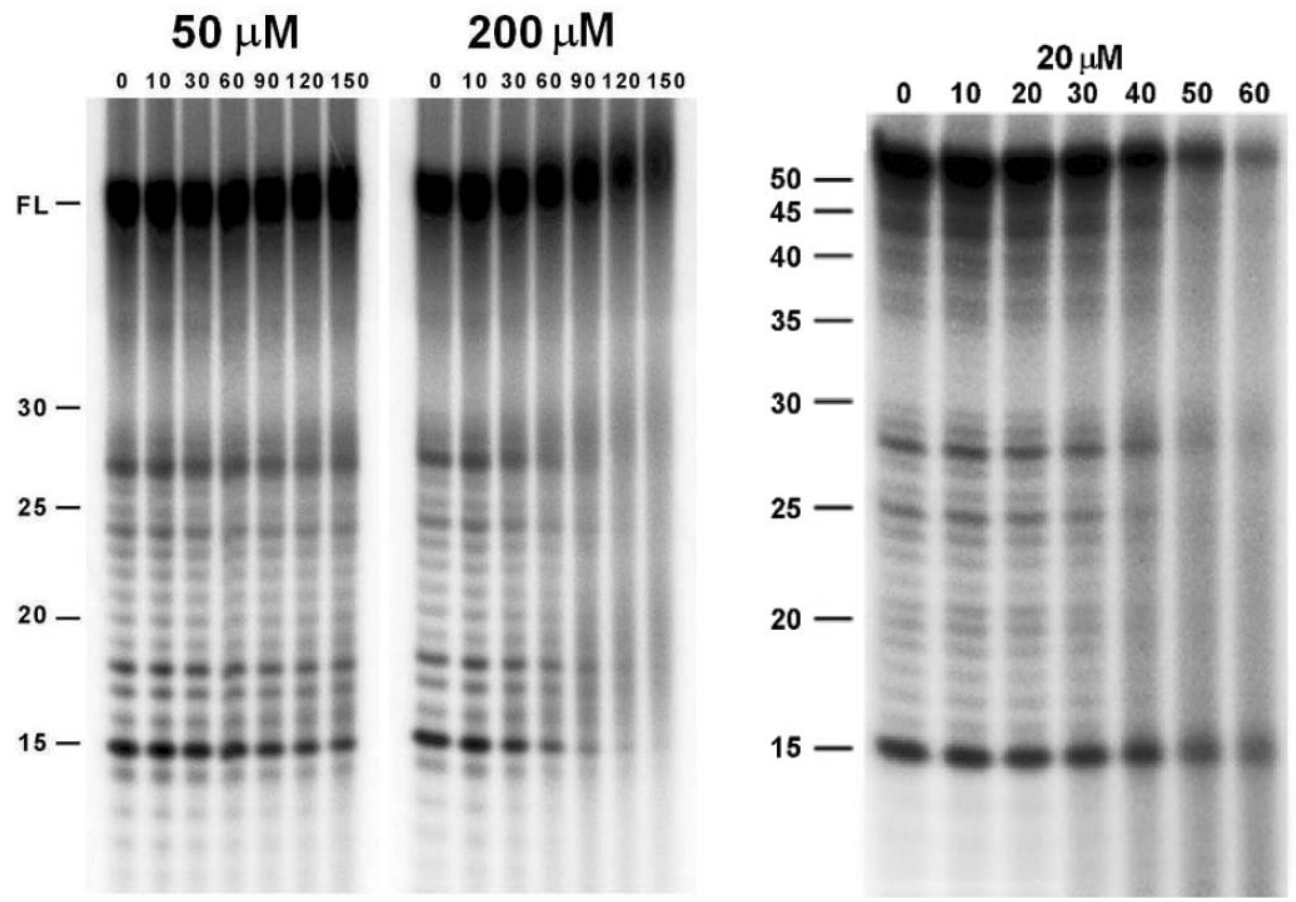

Fig. 5 High-resolution analysis of the cleavage process induced by the compounds PtL-Cl and CuL-Cl. A 54 base pair double-stranded DNA fragment was incubated with PtL-Cl for 0-150 min (left) and with $\mathrm{CuL}-\mathrm{Cl}$ for $0-60 \mathrm{~min}$ (right). DNA size marker in nucleotides (nt) is shown on the left side of the figure. Time $(\mathrm{min})$ is indicated above the lanes. The probe was uniquely radiolabeled at the $5^{\prime}$ end of the top strand. Smearing demonstrates multiple cleavages of nucleotides. 

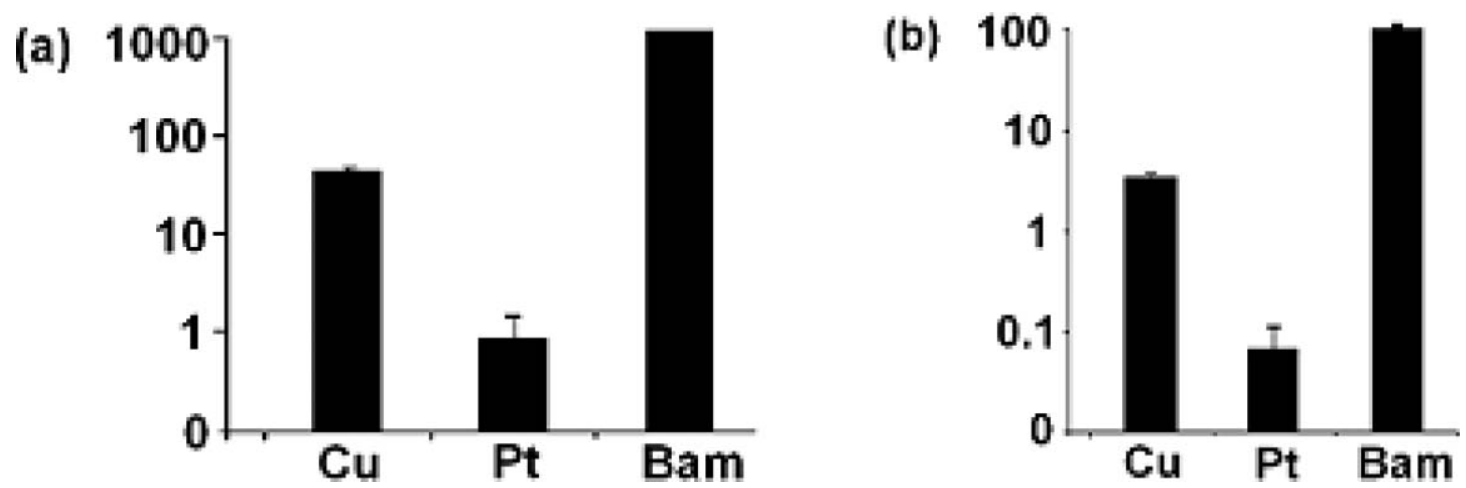

Fig. 6 Relative efficiency of cleavage activity of PtL-Cl and CuL-Cl on pUC19 DNA as (a) CFU per ng DNA and (b) relative CFU. Bam: DNA digested with restriction enzyme BamHI; $\mathbf{C u}$ : DNA cleaved with $\mathrm{CuL}-\mathrm{Cl}$ and Pt: DNA cleaved with PtL-Cl. In all experiments the DNA was religated with T4 DNA ligase and then transformed to $E$. coli cells. CFU, colony forming units after transformation of $E$. coli cells with the DNA samples. Note that $\mathrm{Cu}$-cleaved DNA was restored much more efficiently by religation than Pt-cleaved DNA.

samples contained calf thymus DNA (CT DNA, $100 \mu \mathrm{M}$ per base) in the presence or absence of a metal compound $(1 \mathrm{mM})$ in $10 \mathrm{mM}$ phosphate buffer $(\mathrm{pH}=7.2)$. The ionic strength was kept constant at $50 \mathrm{mM}$. Therefore, the $\mathrm{R}$ value remained constant at 0.1 for all investigated compounds. The metal compounds do not exhibit any $\mathrm{CD}$ in the chosen region of scan. The samples were incubated at physiological temperature $\left(37^{\circ} \mathrm{C}\right)$ and the $\mathrm{CD}$ spectra were recorded at certain time intervals $(10 \mathrm{~min}$ intervals up to $60 \mathrm{~min}$ and then $1 \mathrm{~h}$ intervals up to $12 \mathrm{~h}$ of incubation time). Cisplatin was used as a reference under identical experimental conditions. The changes observed in the native right-handed B-form DNA on interaction with the compounds are shown in Fig. 7(a-d). The panels $7 \mathrm{a}$ and $7 \mathrm{~b}$ show the changes in the CD signal with short and long incubation times, respectively, upon addition of $\mathrm{PtL}-\mathrm{Cl}$, whereas the panels $7 \mathrm{c}$ and $7 \mathrm{~d}$ show the changes in the $\mathrm{CD}$ signal upon addition of $\mathrm{CuL}-\mathrm{Cl}$.
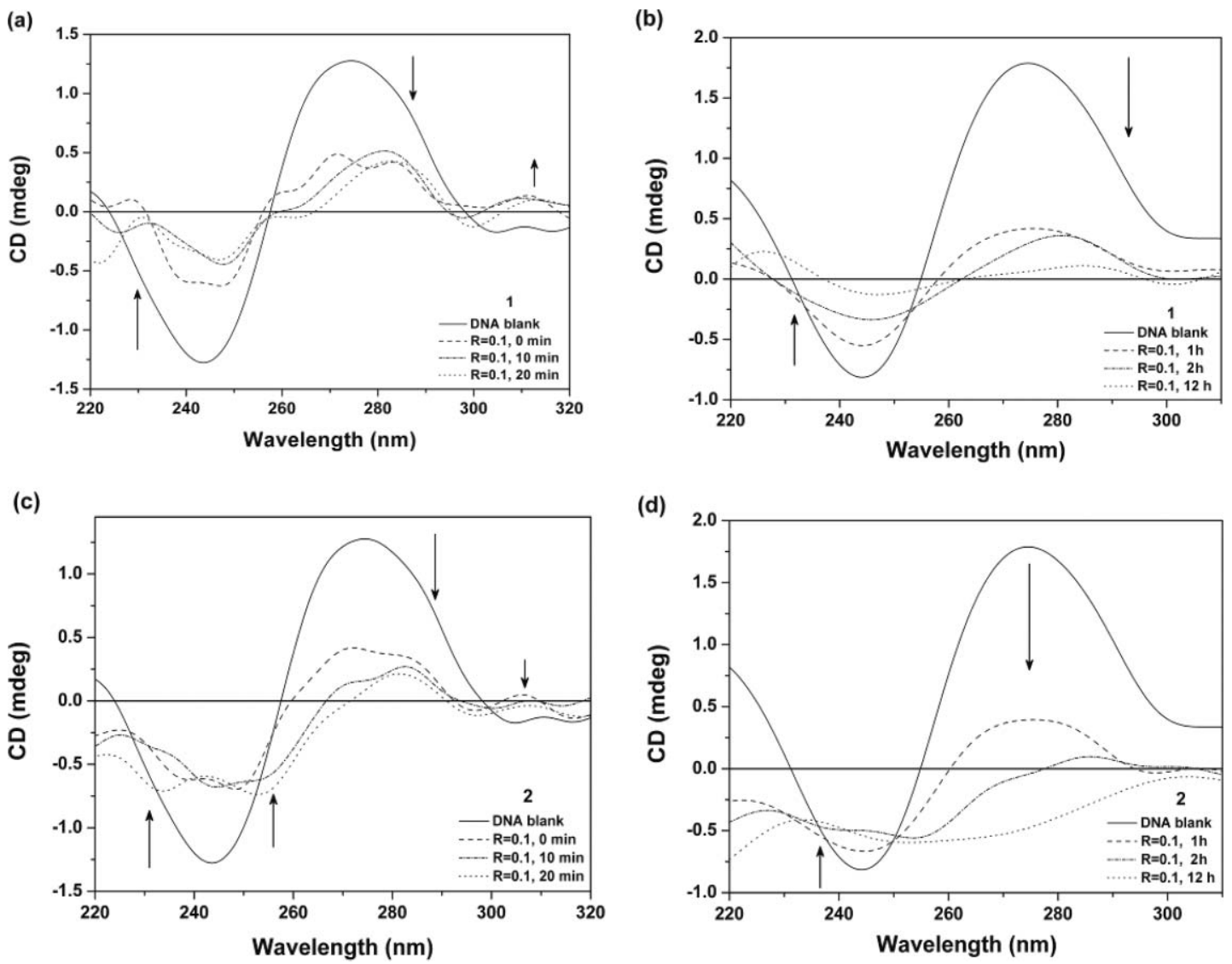

Fig. 7 Time-dependent conformational changes of right-handed DNA upon addition of PtL-Cl and CuL-Cl, in phosphate buffer (10 $\mathrm{mM})$ at $\mathrm{pH}=7.2$ at $37{ }^{\circ} \mathrm{C}$ with $\mathrm{R}=0.1$. The panels (a) and (c) show the changes in the $\mathrm{CD}$ signal for PtL-Cl (1) and CuL-Cl (2), respectively, after a short reaction time. The panels (b) and (d) show the changes in the CD signal after prolonged exposure of CT-DNA to PtL-Cl and CuL-Cl, respectively. 
The right handed B-DNA exhibits dramatic changes on its characteristic positive and negative bands at 272 and $248 \mathrm{~nm}$, respectively, on interaction with of $\mathrm{PtL}-\mathrm{Cl}$ and $\mathrm{CuL}-\mathrm{Cl}$ [Fig. 7(ad)]. The changes started immediately after addition of the compounds to the DNA solution and were observed till $12 \mathrm{~h}$ after incubation. PtL-Cl induces a decrease in intensity for both the positive $(272 \mathrm{~nm})$ and negative bands $(248 \mathrm{~nm})$. Also, new negative (at $230 \mathrm{~nm}$ ) and positive (at $310 \mathrm{~nm}$ ) bands were observed, respectively, as part of the DNA structural degradation. The decrease in positive band intensity indicates destabilization of base-stacking and the decrease in the negative band intensity points to loss in right-handed helicity. ${ }^{41} \mathrm{~A}$ similar behaviour was observed for $\mathrm{CuL}-\mathrm{Cl}$. The changes observed immediately on incubation of $\mathrm{PtL}-\mathrm{Cl}$ and $\mathrm{CuL}-\mathrm{Cl}$ reveal the DNA degradation or unwinding due to strong interaction with the compounds. Also the systematic decrease in the intensities of the bands is a proof for a uniform, specific type of interaction for the PtL-Cl and $\mathrm{CuL}-\mathrm{Cl}$ with DNA, rather than a random mode of interaction. The total loss of the DNA helicity and disruption of the base stacking can be easily correlated to the DNA cleavage activity of PtL-Cl and $\mathrm{CuL}-\mathrm{Cl}^{42}$ In a recent report ${ }^{41}$ the reduction in the intensity of the positive band is reported to originate from interstrand crosslinks to DNA (similar as transplatin). Indeed, the single chloride can be hydrolysed forming a positively charged species that can assist the first electrostatic interaction of the metal compounds with the DNA strand, followed by intercalation of the planar ligand between the base pairs. Therefore, the combined effect of intercalation and coordination is probable for both $\mathrm{PtL}-\mathrm{Cl}$ and $\mathrm{CuL}-\mathrm{Cl}$, to allow an effective DNA interaction and cause oxidative damage. ${ }^{41,43}$

The CD spectral changes in DNA induced by the starting free ligand, Hpyramol is shown in Fig. S3. $\uparrow$ The concentrations of DNA used were $50 \mu \mathrm{M}$ (per base) and $500 \mu \mathrm{M}$ ligand, with the same $\mathrm{R}$ value of 0.1 as in the other samples. There is a slight hyperchromic change in the positive maxima $(278 \mathrm{~nm})$ with a blue shift of $2 \mathrm{~nm}$. The reduction in intensity of the negative band and its $1 \mathrm{~nm}$ red shift are also well marked. The appearance of the new band at $230 \mathrm{~nm}$ is observed for both PtL-Cl and $\mathrm{CuL}-\mathrm{Cl}$. In spite of the changes in intensity, the base-stacking and right-handed helicity are retained, revealing that the ligand only interacts, probably through intercalation with DNA, but does not induce DNA cleavage. Thus the CD spectral changes can be directly correlated with the DNA-cleavage properties observed with agarose gel electrophoresis.

The reference compound, cisplatin, is a classical example of a metallodrug which binds to DNA by coordination. The CD spectra in the presence of cisplatin remain mostly unperturbed as a function of time (Fig. S3†). Initially the positive band intensity slightly decreased and $2 \mathrm{~nm}$ red shift was observed after $12 \mathrm{~h}$ of incubation. The base stacking remained stabilised in time and the helicity of the right-handed B-DNA was found slightly disturbed. The reduced intensity in the negative maximum (248 $\mathrm{nm}$ ) can be easily explained by the unwinding of the helix/or by DNA kinking, which is caused by intrastrand and interstrand crosslinks. Similar CD spectral changes were observed for all above compounds, when the $\phi \mathrm{X} 174$ supercoiled phage DNA was used for measurements instead of calf thymus DNA (data not shown).

\section{Spectro-electrochemical studies}

Cyclic voltammetric scans of $\mathrm{PtL}-\mathrm{Cl}$ at a $\mathrm{Pt}$ microdisk electrode were conducted at room temperature in dry deaerated DMF. In the anodic region, the cyclic voltammogram shows an irreversible wave $(\mathrm{O} 1)$ at $E_{\mathrm{p}, \mathrm{a}}=+1.28 \mathrm{~V}$ vs $\mathrm{Ag} / \mathrm{AgCl}$ for $v=100 \mathrm{mV} \mathrm{s}^{-1}$ (Fig. 8a). A well-separated cathodic wave (R1) is observed at $E_{\mathrm{p}, \mathrm{c}}=$ $+0.25 \mathrm{~V}$ on the reverse scan. The reference compound $\mathrm{CuL}-\mathrm{Cl}$

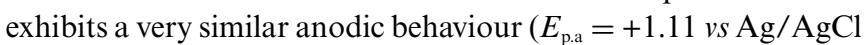
in $\mathrm{MeCN}$ ), which was explained by axial solvent coordination to oxidised $[\mathrm{CuL}-\mathrm{Cl}]^{+}{ }^{44}$ The anodic peak is attributed to the oxidation of the phenolate part of the coordinated pyrimol ligand to phenoxyl radical. The largely pyrimol (phenolate) localised oxidation $^{44}$ corresponds with the similar oxidation potentials of PtL-Cl and $\mathrm{CuL}-\mathrm{Cl}$. The small $E_{\mathrm{p}, \mathrm{a}}$ shift may have origin in different kinetics of the coupled chemical reaction (solvent coordination) and/or reflects the minor contribution of metal $\mathrm{d}$ orbitals into the HOMO. A better insight should be obtained by DFT calculations of PtL-Cl which, however, were considered as out of scope of this work. The phenolate oxidation in PtL-Cl can also be compared with the oxidation of the dehydrogenated Hpyrimol ligand in DMF (Fig. 8b), which is also irreversible and slightly positively shifted to $E_{\mathrm{p}, \mathrm{a}}=+1.35 \mathrm{~V}$ vs $\mathrm{Ag} / \mathrm{AgCl}$. In the latter case, however, the coupled chemical reaction might have a different origin (e.g., deprotonation).
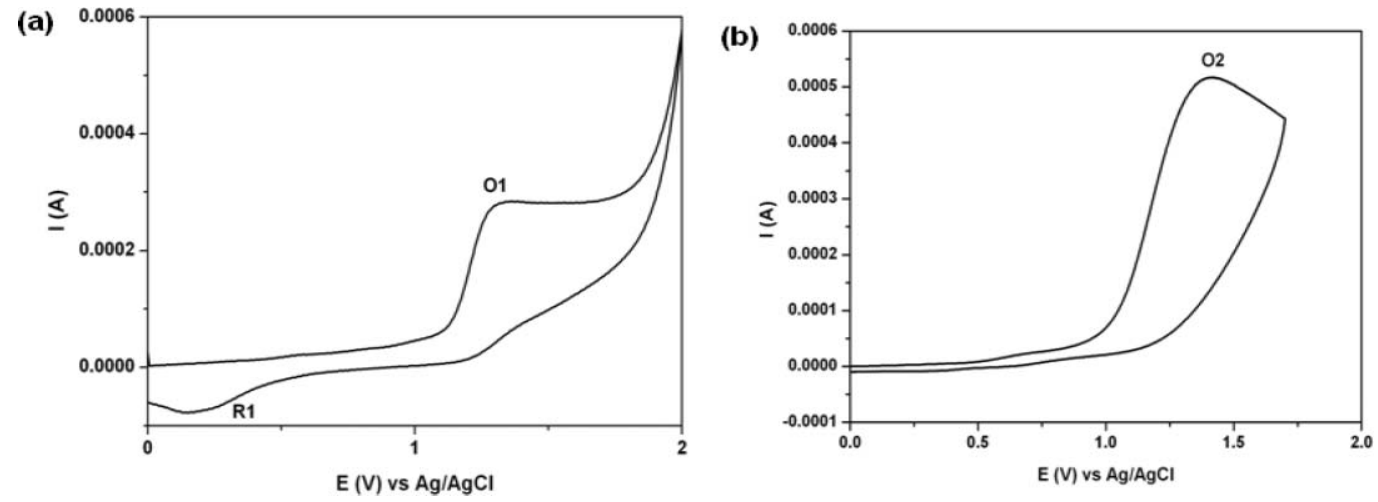

Fig. 8 Cyclic voltammograms of $10^{-3} \mathrm{M} \mathrm{PtL}-\mathrm{Cl}$ (a) and the free ligand, Hpyrimol (b) in the anodic region. Conditions: freshly polished Pt working electrode (apparent surface area of $0.312 \mathrm{~cm}^{2}$ ), $v=100 \mathrm{mV} \mathrm{s}^{-1}, \mathrm{DMF} / 10^{-1} \mathrm{M} \mathrm{Bu}_{4} \mathrm{NPF}_{6}$, room temperature. 
The UV-Vis spectrum of PtL-Cl in dry DMF shows prominent absorption bands at 620,425 and $310 \mathrm{~nm}$. These bands are replaced during the oxidation at the $\mathrm{O} 1$ electrode potential $(+1.28 \mathrm{~V} v s$ $\mathrm{Ag} / \mathrm{AgCl}$ ) by new absorptions at 260 (sh) and 380 (sh) $\mathrm{nm}$ and a poorly resolved absorption between 400-600 nm (Fig. 9). The visible absorption of the oxidised species reflects the presence of the phenoxyl radical ligand $\left(\mathrm{L}^{*}\right)$ derived from pyrimol. The $\mathrm{UV}-\mathrm{V}$ is spectrum of short-lived free $\mathrm{L}^{*}$ (shoulder at $\left.c a .430 \mathrm{~nm}\right)^{45}$ is shown in the Supporting Information (Fig. S4 $\dagger$ ). For oxidised $\left[\mathrm{CuL}^{-}-\mathrm{Cl}\right]^{+}$, the corresponding electronic transitions between $400-500 \mathrm{~nm}$ were shown by TD-DFT to have a mixed intraligand $\left(\mathrm{L}^{*}\right)$ and chargetransfer $\left(\mathrm{Cu}\right.$-to- $\left.\mathrm{L}^{*}\right)$ character. ${ }^{44}$ The involvement of the transition metal centre in the visible electronic excitation may explain the low-energy shift of the absorption to $500-600 \mathrm{~nm}$ for $\left[\mathrm{PtL}^{-}-\mathrm{Cl}\right]^{+}$ (Fig. 9) compared to $\mathrm{CuL-Cl.}$

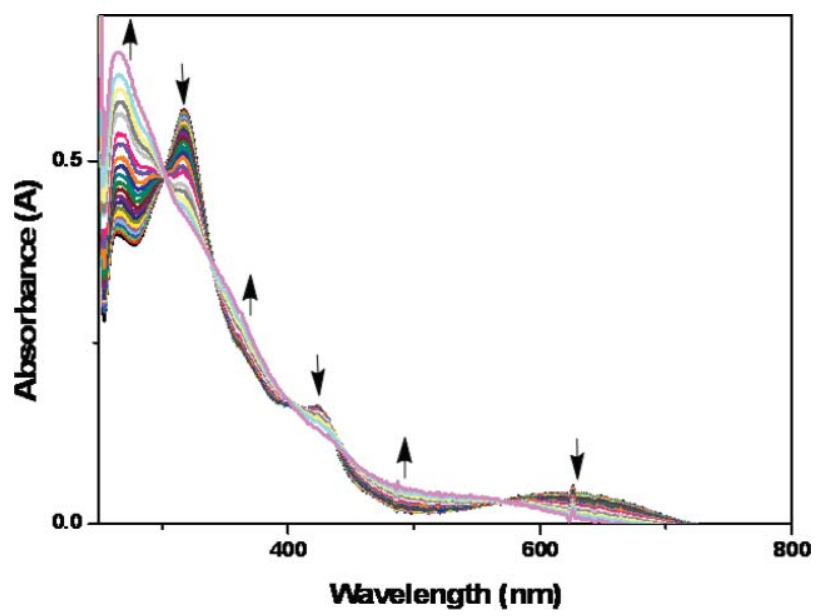

Fig. 9 UV-Vis spectral changes accompanying the rapid oxidation of $\mathrm{PtL}-\mathrm{Cl}$ at the electrode potential $\mathrm{O} 1$ to a phenoxyl radical species in DMF at room temperature, using an OTTLE cell.

Differently from fairly stable $[\mathrm{CuL}-\mathrm{Cl}]^{+}$that could be reduced back on the time scale of min to largely recover the neutral parent compound, ${ }^{44}$ the oxidised $\left[\mathrm{PtL}^{-}-\mathrm{Cl}\right]^{+}$species is more reactive at room temperature, as concluded from a constant decay of its absorption in the OTTLE cell prior to the reverse reduction at the cathodic wave R1. The apparent difference in the relative stability of the phenoxyl radical complexes may explain the higher (catalytic) activity of $\mathrm{CuL}-\mathrm{Cl}$ towards the DNA substrate, as described in this work. The species $\left[\mathrm{CuL}^{-}-\mathrm{Cl}\right]^{+}$was shown by cyclic voltammetry to bind reversibly a solvent molecule, probably at the axial position. ${ }^{44}$ In strictly square planar $\left[\mathrm{PtL}^{-}-\mathrm{Cl}\right]^{+}$the expected strong trans effect labilises the $\mathrm{Pt}-\mathrm{Cl}$ bond, causing dissociation of the chloride ligand and solvent coordination, being probably coupled to further reactivity. The existence of the solventsubstituted species $[\mathrm{Pt}(\text { pyrimol })(\mathrm{Sv})]^{+}(\mathrm{Sv}=\mathrm{DMF}$ or $\mathrm{DMSO})$ formed during the reaction of $\mathrm{PtL}-\mathrm{Cl}$ with model DNA bases in these donor solvents, as revealed by ESI-MS (see below), supports strongly this argumentation.

\section{Reactions with DNA model bases}

9-Ethylguanine. The reaction between $\mathrm{PtL}-\mathrm{Cl}$ and 9-EtG, typically in the molar ratios $1: 1$ and $1: 4$, was monitored by ${ }^{1} \mathrm{H}$ and ${ }^{195} \mathrm{Pt}$ NMR spectroscopy. 9-EtG was dissolved in DMSO- $d_{6}$ and spectra were recorded at physiological temperature $\left(37^{\circ} \mathrm{C}\right)$. Also the time-dependent ESI-MS studies were performed to determine the relative formation rate of the adduct. The reaction mixture showed the presence of unreacted reagents (PtL-Cl and 9-EtG) and very small peaks arising from the mono-adduct independently of the molar excess of the model base. The time-dependent serial spectra ( ${ }^{1} \mathrm{H}$ NMR) showed only small changes (Fig. 10). However, a new peak in ${ }^{195} \mathrm{Pt}$ NMR at -2405 ppm was clearly observed after $48 \mathrm{~h}$, which can be assigned to a $\mathrm{PtN}_{3} \mathrm{O}$ moiety.

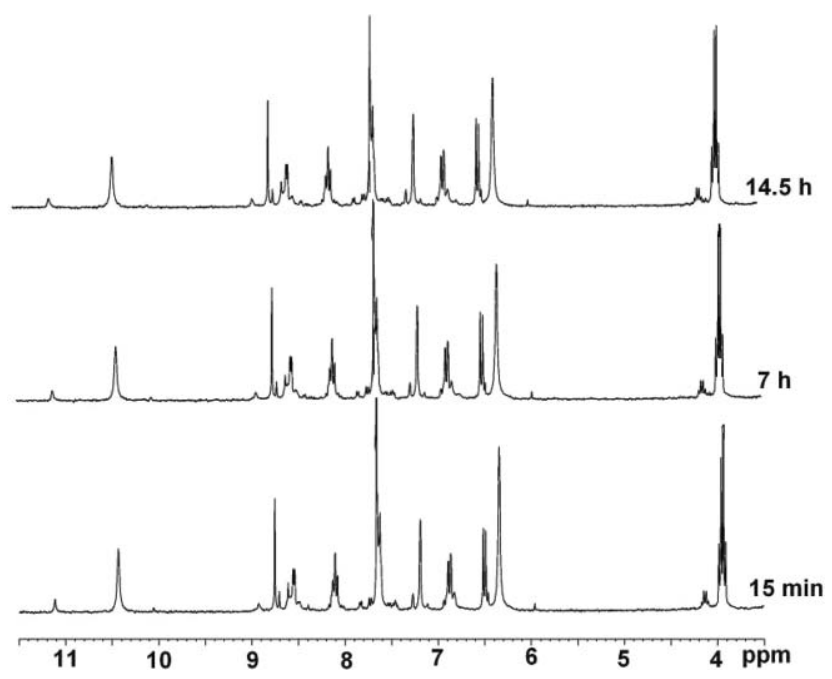

Fig. 10 Stacked ${ }^{1} \mathrm{H}$ NMR spectra of PtL-Cl in presence of 9-EtG (1:1) in DMSO- $d_{6}$ at $37^{\circ} \mathrm{C}$.

The ESI-MS also proves the gradual evolution of the adduct, $[\mathrm{Pt}$ (pyrimol)(9-EtG)]Cl at $m / z=620.96$. In the reaction mixture the species present can be assigned as (a) $[\mathrm{Pt}(\text { pyrimol })(\mathrm{dmso})]^{+}$; $m / z=483.91$, (b) $[\mathrm{Pt}(\text { pyrimol })(9-\mathrm{EtG})]^{+} ; \mathrm{m} / \mathrm{z}=585.86$; (c) $\left[\mathrm{Pt}(\text { pyrimol)(9-EtG) }(\mathrm{dmso})]^{+} ; m / z=662.79\right.$, (d) $9-\mathrm{EtG} ; m / z=$ 178.92 and (e) $9-E t G+D M S O ; m / z=253.99$. The platinumcontaining species show the typical $\mathrm{Pt}$ isotopic pattern. The major component of the reaction mixture is the solvated product, $[\mathrm{Pt}(\text { pyrimol })(\mathrm{dmso})]^{+}$. The reaction is not immediate, but the appearance of this mono-adduct was observed by ESI-MS (see Fig. S5 $\dagger$ ) and NMR only after $24 \mathrm{~h}$.

5'-Guanosine monophosphate. PtL-Cl was allowed to react with this model base in different molar ratios (namely 1:1 and 1:4) in a solvent mixture of DMSO- $d_{6}$ and $\mathrm{D}_{2} \mathrm{O}$ at $37^{\circ} \mathrm{C}$. The changes in NMR and ESI-MS spectra were followed in certain time intervals. The poor solubility of PtL-Cl in aqueous solvent and no solubility of GMP in organic solvent, limits the use of PtL-Cl at high concentrations. The clear progress of ${ }^{1} \mathrm{H}$ NMR changes is shown in stacked spectra (Fig. 11). The ${ }^{195} \mathrm{Pt}$ NMR revealed a new signal at $-2820 \mathrm{ppm}$ after $24 \mathrm{~h}\left(\mathrm{~N}_{2} \mathrm{OS}\right.$ coordination environment around $\mathrm{Pt})^{39,40}$ quite changed from the peak from the starting compound PtL-Cl at -2319 ppm (in DMSO- $d_{6}+\mathrm{D}_{2} \mathrm{O}$ ). Results of a timedependent ESI-MS study performed in DMF (shown in Fig. S6) document the presence of a mixture of adducts assigned (a) $[\mathrm{Pt}(\text { pyrimol })(\mathrm{dmf})]^{+}$(i.e., solvolysis in presence of DMF); $m / z=$ 479.87, (b) $[\mathrm{Pt} \text { (pyrimol) }]^{+}+3 \mathrm{CH}_{3} \mathrm{OH}$ (eluting solvent); $m / z=$ 537.86 (major), (c) $\left[\mathrm{Pt}(\text { pyrimol) }]^{+}+2 \mathrm{DMF} ; m / z=552.82\right.$, (d) $[\mathrm{Pt}($ pyrimol)(GMP) $] ; m / z=842.97$, (e) $[\mathrm{Pt}($ pyrimol $)(\mathrm{GMP})]+$ $\mathrm{DMF} ; m / z=921.71$. Therefore the mono-substituted adduct can 


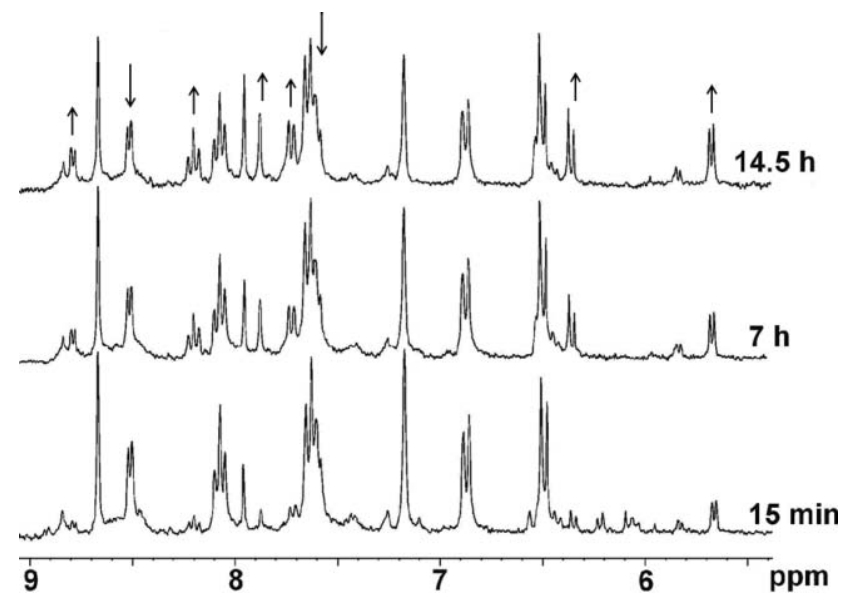

Fig. 11 Time-dependent changes in ${ }^{1} \mathrm{H}$ NMR spectra of PtL-Cl upon addition of $5^{\prime}$-GMP in DMSO- $d_{6}+\mathrm{D}_{2} \mathrm{O}$ at $37^{\circ} \mathrm{C}$. The arrows show gradual changes (rise of a new peak [up] or decrease of a peak [down] with time).

be identified, but the solvent-coordinated species is the major one and is not easily substituted by model base.

\section{Interaction with d(GTCGAC)}

The interaction of PtL-Cl with the self complementary oligonucleotide d(GTCGAC) ${ }_{2}^{46}$ was carried out at different temperatures ranging from $4-47^{\circ} \mathrm{C}$ to obtain a slow or fast proton exchange rather than an intermediate exchange. ${ }^{1} \mathrm{H}$ NMR spectra were recorded in $90 \% \mathrm{H}_{2} \mathrm{O}$ and $10 \% \mathrm{D}_{2} \mathrm{O}$ to follow any changes in the amine/imine protons of the oligonucleotide. The variable temperature 1-D, ${ }^{1} \mathrm{H}$ NMR experiments show that at $17{ }^{\circ} \mathrm{C}$ (Fig. S7) and $27^{\circ} \mathrm{C}$ (Fig. S8) $\dagger$ fast exchanges were observed and the Tables 4 and 5 clearly describes the proton shifts (in ppm) for the $\mathrm{PtL}-\mathrm{Cl}$ (free) and after interacting with the oligonucleotide at $17^{\circ} \mathrm{C}$ and $27^{\circ} \mathrm{C}$. The used numbering of the protons is depicted in the insert with the ${ }^{1} \mathrm{H}$ NMR spectra in Fig. S8. $\dagger$ The assignments were based on 2D DQF-COSY, through bond interactions at $27{ }^{\circ} \mathrm{C}$; they were done for the pure $\mathrm{PtL}-\mathrm{Cl}$ compound and for $\mathrm{PtL}-\mathrm{Cl}$ after interaction with the oligonucleotide at $27^{\circ} \mathrm{C}$ (Figs. S9 and S10). $\dagger$ In general, the bound compound shows large shifts of the ligand proton signals, especially in the phenolate part $(3 \mathrm{H}$ and $4 \mathrm{H}$ ) compared to the less affected methylene protons (signal $9 \mathrm{H}$ ) and medium shifted pyridine ring proton signals $11 \mathrm{H}$ to $14 \mathrm{H}$, (Figs. S8 and S11). $\dagger$ The totally decayed appearance of signal

Table $4{ }^{1} \mathrm{H}$ NMR signals ( $\delta$ in ppm) of PtL-Cl before and after the interaction with oligonucleotide

\begin{tabular}{llll}
\hline & & $\begin{array}{l}\text { In the presence of } \\
\mathrm{d}(\mathrm{GTCGAC})_{2} \text { at }\end{array}$ & $\begin{array}{l}\text { In the presence of } \\
\mathrm{d}(\mathrm{GTCGAC})_{2} \text { at } \\
1{ }^{\circ} \mathrm{C}\end{array}$ \\
\hline PtL-Cl-protons & $\begin{array}{l}\text { No } \\
2{ }^{\circ} \mathrm{C}\end{array}$ & 8.23 \\
$3(\mathrm{~d})$ & 6.89 & 8.22 & 7.71 \\
$4(\mathrm{~d})$ & 6.50 & 7.72 & 7.60 \\
$6(\mathrm{~s})$ & 8.77 & 7.58 & 7.38 \\
$9(\mathrm{~s})$ & 7.20 & 7.34 & 7.90 \\
$11(\mathrm{~d})$ & 7.64 & 7.96 & 8.16 \\
$12(\mathrm{t})$ & 8.12 & 8.17 & 7.41 \\
$13(\mathrm{t})$ & 7.64 & 7.43 & 7.97 \\
$14(\mathrm{~d})$ & 8.55 & 7.98 & \\
\hline
\end{tabular}

Table $5{ }^{1} \mathrm{H}$ NMR signals ( $\delta$ in ppm) of oligonucleotide before and after interaction with PtL-Cl

\begin{tabular}{llll}
\hline d(GTCGAC $)_{2}-$ protons & $\begin{array}{l}\text { Free } \\
(\text { no PtL-Cl })\end{array}$ & $\begin{array}{l}\text { With PtL-Cl } \\
\text { at 27 }{ }^{\circ} \mathrm{C}\end{array}$ & $\begin{array}{l}\text { With PtL-Cl } \\
\text { at } 17{ }^{\circ} \mathrm{C}\end{array}$ \\
\hline 8H of G1 & 7.946 & 8.016 & 8.031 \\
8H of G4 & 7.458 & 7.982 & 8.031 \\
8H of A5 & 7.921 & 7.982 & 8.014 \\
2H of A5 & 8.132 & 8.053 & 8.052 \\
5H of C3 & 5.589 & 6.523 & 6.520 \\
5H of C6 & 5.262 & 6.940 & 6.963 \\
6H of C3 & 7.446 & 6.725 & 6.712 \\
6H of C6 & 7.257 & 7.114 & 7.124 \\
6H of T2 & 7.496 & 7.535 & 7.538 \\
$2^{\prime}$ & $1.8-3.0$ & - & - \\
$4^{\prime} ; 5^{\prime}$ & $3.7-4.5$ & - & - \\
$3^{\prime}$ & $4.4-5.2$ & - & - \\
$1^{\prime}$ & $5.3-6.3$ & - & - \\
\hline
\end{tabular}

11 and the approximately $1.5 \mathrm{ppm}$ downfield shifts observed for the signals $3 \mathrm{H}$ and $4 \mathrm{H}$, clearly reveal the intercalating mode of interaction for the PtL-Cl through the pyrimol ligand between the nucleobases. Further, the shifts of the oligonucleotide proton signals can be observed for all the base protons, but the highest is with cytosine $(\mathrm{C} 3 \mathrm{H} 5, \mathrm{C} 3 \mathrm{H} 6)$ and guanine $(\mathrm{G} 4 \mathrm{H} 8)$ protons in the central position of the oligonucleotide. Again, the proton assignment was achieved by comparing the 2-D DQF-COSY spectrum of the free oligonucleotide and the 2-D DQF-COSY spectrum of $\mathrm{d}(\mathrm{GTCGAC})_{2}$ interacting with $\mathrm{PtL}-\mathrm{Cl}$ at $27^{\circ} \mathrm{C}$. The sugar protons could not be followed individually, due to broad and merged signals after interaction with the Pt compound. The same kind of broadened signals were observed for the amino/imino protons, immediately after interacting with $\mathrm{PtL}-\mathrm{Cl}$, making it difficult to follow the signal in time, also in 2-D experiments. Based on the assignments, the NOESY spectrum at $27{ }^{\circ} \mathrm{C}$ was also analysed to detect any through space interactions between the oligonucleotide and PtL-Cl (within $4 \AA$, Fig. S12). $\dagger$ The cross peaks observed between (i) the ligand proton 9 to $\mathrm{C} 3 \mathrm{H} 5 / \mathrm{C} 6 \mathrm{H} 5$; (ii) 6 to the $1^{\prime}$ sugar protons and (iii) 13 the $3^{\prime}$ sugar protons, are important to reveal that the compound tends to interact in the minor groove of the oligonucleotide at the fast exchange rate. ${ }^{47}$ That is from the $\mathrm{C} 3$ to the $\mathrm{C} 6$ region of $\mathrm{d}(\mathrm{GTCGAC})_{2}$, which is also obvious from the proton shifts associated with the corresponding bases. For the small molecules like $\mathrm{Cu}(\text { phen })^{2+}$ the minor groove binding is suggested for a compact and closer DNA interaction. Thus the simple, planar PtL-Cl could also be expected to interact initially with DNA in the minor groove. The unassigned peaks observed in the 1-D spectra (data not shown) after $8 \mathrm{~h}$ of interaction can be assumed as arising from the cleaved DNA (sugars/bases), which again supports a non-specific DNA cleavage event occurring on interaction with PtL-Cl.

\section{Conclusions}

A novel platinum compound was synthesised and characterised in detail by NMR and X-ray analysis. The $\mathrm{Pt}(\mathrm{II})$ ion is in a square-planar coordination environment with the ligand having a tripodal (N,N,O) chelating motif. The ligand precursor Hpyramol was found to dehydrogenate and form the pyrimol anion that binds firmly to $\mathrm{Pt}(\mathrm{II})$. This compound induces single-strand scission of supercoiled DNA, just like the previously reported ${ }^{26}$ 
analogue $\mathrm{CuL}-\mathrm{Cl}$, albeit in stoichiometric concentrations rather than catalytic amounts. Both compounds show high to modest in vitro cytotoxic properties against various cancer cell lines. The cancer cell-growth inhibition ability appears to be strongly timedependent and selective towards some cell lines. The cytotoxic activity induced by $\mathrm{CuL}-\mathrm{Cl}$ may be explained by catalytic DNA cleavage, which results in irreparable damage, different cellular processing and the bioavailability inside the cells. The comparatively low activity of PtL-Cl indicates reversible DNA damage, facile repair mechanism, higher stability of solvated intermediate and non-availability of the active species in intracellular medium. To correlate the DNA cleavage properties, in vitro cytotoxicity and the DNA structural changes, several techniques were used to provide mechanistic insights.

The spectro-electrochemical studies of $\mathrm{PtL}-\mathrm{Cl}$ in comparison with $\mathrm{CuL}-\mathrm{Cl}$ and free Hpyrimol provide supportive evidence for the formation of a phenoxyl radical and its likely involvement in oxidative DNA-cleavage. The structural changes of the DNA were followed by circular dichroism and gel mobility studies and the observed DNA degradation by $\mathrm{PtL}-\mathrm{Cl}$ was further analysed in detail by high-resolution gel electrophoresis. These experiments not only indicated extensive DNA degradation, but also demonstrated that PtL-Cl cleaves nucleotides simultaneously or sequentially at multiple positions. The reactions of PtL-Cl with DNA model bases (9-ethylguanine and 5'-GMP; 1:1) at physiological temperature exhibit the slow formation of monoadducts with chloride substitution via solvolysis. Our studies also highlighted that $\mathrm{PtL}-\mathrm{Cl}$ primarily interacts with the minor groove of the DNA, in contrast to cisplatin which preferentially binds to the major groove.

The title compound $\mathrm{PtL}-\mathrm{Cl}$ induces significant damage to isolated DNA under experimental in vitro conditions of biophysical studies; however, DNA damage inside the cancer cells might be easily reparable. Being a monofunctional compound, PtL-Cl induces comparatively lower cytotoxicity than cisplatin in a panel of cell lines. The mono-adduct formed on the DNA helix in the minor groove by small $\mathrm{PtL}-\mathrm{Cl}$, is unable to widen the minor groove. As a result the typical 'kink' of cisplatin interaction is not induced and the DNA degradation is eventually repaired by the cell machinery.

Thus the DNA-targeting monofunctional platinum compound possessing dual intercalation-coordination property in fact acts as minor-groove binder and simultaneously overcomes the resistance. The present work, including all the mechanistic studies, strongly suggests that a controlled modification, could lead to new, potential antitumour compounds that can survive the repair mechanism and induce facile apoptosis.

\section{Acknowledgements}

We are grateful to Prof. Dr. Jaap Brouwer for his support (inhouse cytotoxicity and uptake) and to TEVA-Pharmachemie, Haarlem (The Netherlands) for conducting the cell viability assays. Johnson-Matthey (Reading, UK) is gratefully thanked for their generous donation of $\mathrm{K}_{2} \mathrm{PtCl}_{4}$. The work described here was financially supported (M. L., A. L. S.) by the Council for Chemical Sciences of the Netherlands Organization for Scientific Research (CW-NWO).

\section{References}

1 L. Kelland, Nat. Rev. Cancer, 2007, 7, 573-584.

2 B. Lippert, Cisplatin, Chemistry and Biochemistry of a Leading Anticancer Drug, Wiley-VCH, Weinheim, 1999.

3 L. Kelland, Expert Opin. Invest. Drugs, 2007, 16, 1009-1021.

4 E. R. Jamieson and S. J. Lippard, Chem. Rev., 1999, 99, 2467-2498.

5 J. Reedijk, Chem. Rev., 1999, 99, 2499-2510.

6 J. Reedijk, Curr. Opin. Chem. Biol., 1999, 3, 236-240.

7 Y. W. Jung and S. J. Lippard, Chem. Rev., 2007, 107, 1387-1407.

8 D. Wang and S. J. Lippard, Nat. Rev. Drug Discovery, 2005, 4, 307-320.

9 J. Reedijk, Proc. Natl. Acad. Sci. U. S. A., 2003, 100, 3611-3616.

10 J. Reedijk, Platinum Met. Rev., 2008, 52, 2-11.

11 M. D. Hall, M. Okabe, D. W. Shen, X. J. Liang and M. M. Gottesman, Annu. Rev. Pharmacol. Toxicol., 2008, 48, 495-535.

12 X. Gao, X. Wang, J. Ding, L. Lin, Y. Li and Z. Guo, Inorg. Chem. Commun., 2006, 9, 722-726.

13 F. Huq, J. Qing Yu, H. Daghriri and P. Beale, J. Inorg. Biochem., 2004, 98, 1261-1270.

14 H. Tayyem, F. Huq, J. Q. Yu, P. Beale and K. Fisher, ChemMedChem, 2008, 3, 145-151.

15 A. D. Richards and A. Rodger, Chem. Soc. Rev., 2007, 36, 471-483.

16 S. Roy, K. D. Hagen, P. U. Maheswari, M. Lutz, A. L. Spek, J. Reedijk and G. P. van Wezel, ChemMedChem, 2008, 3, 1427-1434.

17 L. S. Hollis, W. I. Sundquist, J. N. Burstyn, W. J. Heiger-Bernays, S. F. Bellon, K. J. Ahmed, A. R. Amundsen, E. W. Stern and S. J. Lippard, Cancer Res., 1991, 51, 1866-1875.

18 R. Guddneppanavar, G. Saluta, G. L. Kucera and U. Bierbach, J. Med. Chem., 2006, 49, 3204-3214.

19 K. S. Lovejoy, R. C. Todd, S. Z. Zhang, M. S. McCormick, J. A. D'Aquino, J. T. Reardon, A. Sancar, K. M. Giacomini and S. J. Lippard, Proc. Natl. Acad. Sci. U. S. A., 2008, 105, 8902-8907.

20 V. Bursova, J. Kasparkova, C. Hofr and V. Brabec, Biophys. J., 2005, 88, 1207-1214.

21 Y. Ma, C. S. Day and U. Bierbach, J. Inorg. Biochem., 2005, 99, $2013-$ 2023.

22 A. T. M. Marcelis, C. Erkelens and J. Reedijk, Inorg. Chim. Acta, 1984, 91, 129.

23 P. de Hoog, M. J. Louwerse, P. Gamez, M. Pitié, E. J. Baerends, B. Meunier and J. Reedijk, Eur. J. Inorg. Chem., 2008, 612-619.

24 L. D. Pachon, A. Golobic, B. Kozlevcar, P. Gamez, H. Kooijman, A. L. Spek and J. Reedijk, Inorg. Chim. Acta, 2004, 357, 3697-3702.

25 P. U. Maheswari, S. Barends, S. Ozalp-Yaman, P. de Hoog, H. Casellas, S. J. Teat, C. Massera, M. Lutz, A. L. Spek, G. P. van Wezel, P. Gamez and J. Reedijk, Chem.-Eur. J., 2007, 13, 5213-5222.

26 P. U. Maheswari, S. Roy, H. den Dulk, S. Barends, G. van Wezel, B. Kozlevcar, P. Gamez and J. Reedijk, J. Am. Chem. Soc., 2006, 128, $710-711$.

27 A. J. M. Duisenberg, L. M. J. Kroon-Batenburg and A. M. M. Schreurs, J. Appl. Crystallogr., 2003, 36, 220-229.

28 G. M. Sheldrick, SADABS: Area-Detector Absorption Correction, (1999) Universität Göttingen, Germany.

29 P. T. Beurskens, G. Admiraal, G. Beurskens, W. P. Bosman, S. GarciaGranda, R. O. Gould, J. M. M. Smits, C. Smykalla, The DIRDIF99 program system, Technical Report of the Crystallography Laboratory, University of Nijmegen, Nijmegen, The Netherlands, 1999.

30 G. M. Sheldrick, Acta Crystallogr., Sect. A: Found. Crystallogr., 2007, 64, 112-122.

31 A. L. Spek, J. Appl. Crystallogr., 2003, 36, 7-13.

32 T. Mosmann, J. Immunol. Methods, 1983, 65, 55-63.

33 Y. P. Keepers, P. E. Pizao, G. J. Peters, J. Vanarkotte, B. Winograd and H. M. Pinedo, European Journal of Cancer and Clinical Oncology, 1991, 27, 897-900.

34 M. R. Boyd, in Cancer: Principles and Practice of Oncology Update, ed. H. De Vita V. T. Jr., S. and S. A. Rosenberg, Lippincott Philadelphia, 1989, vol. 3, pp. 1-12.

35 S. Rigali, F. Titgemeyer, S. Barends, S. Mulder, A. W. Thomae, D. A. Hopwood and G. P. van Wezel, EMBO Rep., 2008, 9, 670-675.

36 M. Krejčik, M. Daněk and F. Hartl, J. Electroanal. Chem., 1991, 317, 179-187.

37 M. A. Weiss, J. L. Eliason and D. J. States, Proc. Natl. Acad. Sci. U. S. A., 1984, 81, 6019-6023.

38 M. Piotto, V. Saudek and V. Sklenáŕ, J. Biomol. NMR, 1992, 2, 661-665.

39 J. R. L. Priqueler, I. S. Butler and F. D. Rochon, Appl. Spectrosc. Rev, 2006, 41, 185-226. 
40 B. M. Still, P. G. A. Kumar, J. R. Aldrich-Wright and W. S. Price, Chem. Soc. Rev., 2007, 36, 665-686.

41 J. Kašpárková, M. Vojtíšková, G. Natile and V. Brabec, Chem.-Eur. J., 2008, 14, 1330-1341.

42 V. Brabec and J. Kašpárková, Drug Resist. Updates, 2005, 8, 131-146.

43 V. Brabec, V. Boudný and Z. Balcarová, Biochemistry, 1994, 33, 13161322.
44 P. U. Maheswari, et al., Eur. J. Inorg. Chem., 2009, to be submitted.

45 V. T. Kasumov, H. Turkmen, I. Ucar, A. Bulut and N. Yayli, Spectrochim. Acta, Part A, 2008, 70, 60-68.

46 P. U. Maheswari, V. Rajendiran, H. Stoeckli-Evans and M. Palaniandavar, Inorg. Chem., 2006, 45, 37-50.

47 J. P. Rehmann and J. K. Barton, Biochemistry, 1990, 29, 1710 1717. 